TI 2017-027/VIII

Tinbergen Institute Discussion Paper
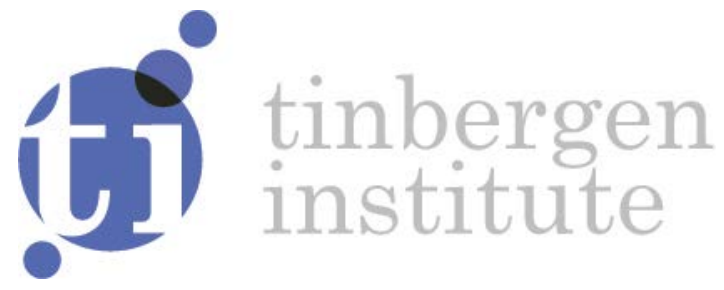

\title{
Follow the money: Does the Financial Sector Intermediate Natural Resource Windfalls?
}

Thorsten Beck ${ }^{1,3}$

Steven Poelhekke $e^{2,3}$ 
Tinbergen Institute is the graduate school and research institute in economics of Erasmus University Rotterdam, the University of Amsterdam and VU University Amsterdam.

Contact: discussionpapers@tinbergen.nl

More TI discussion papers can be downloaded at http://www.tinbergen.nl

Tinbergen Institute has two locations:

Tinbergen Institute Amsterdam

Gustav Mahlerplein 117

1082 MS Amsterdam

The Netherlands

Tel.: $+31(0) 205984580$

Tinbergen Institute Rotterdam

Burg. Oudlaan 50

3062 PA Rotterdam

The Netherlands

Tel.: +31(0)104088900 


\title{
Follow the money: Does the financial sector intermediate natural resource windfalls?
}

\author{
Thorsten Beck * \\ (Cass Business School, City, University of London; and CEPR) \\ Steven Poelhekke ** \\ (Vrije Universiteit Amsterdam; De Nederlandsche Bank; Tinbergen Institute)
}

This version: 18 February 2017

\begin{abstract}
:
The need to absorb windfalls gains and manage them appropriately has been discussed extensively by academics and policy makers alike. We explore the role of the financial sector in intermediating these windfalls. Controlling for the level of financial development, inflation, GDP growth and country fixed-effects, we find a relative decline in financial sector deposits in countries that experience an unexpected natural resource windfall as measured by shocks to exogenous world prices. Moreover, we find a similar relative decline in lending, which is mostly due to the decrease in deposits. The smaller role for the financial sector in intermediating resource booms is accompanied by a stronger role of governments in channeling resources into the economy, mostly through higher government consumption.
\end{abstract}

JEL codes: E20, F41, G20, O10, Q32, Q33

Keywords: natural resources, financial development, banking

* Cass Business School, City University London, CEPR, and CESifo. Contact information: Cass Business School, 106 Bunhill Row, London EC1Y 8TZ, UK. Email: TBeck@city.ac.uk. ** Vrije Universiteit Amsterdam, Tinbergen Institute, CESifo, and De Nederlandsche Bank. Contact information: Vrije Universiteit Amsterdam, Faculty of Economics and Business Administration, De Boelelaan 1105, 1081 HV Amsterdam, The Netherlands. Email: steven.poelhekke@vu.nl. We are greateful for comments by Rabah Arezki, Charles Bos, Rick van der Ploeg, Samuel Wills and participants at the Bank of Algeria conference on Natural Resources, Finance and Growth. Views expressed are those of the authors and do not necessarily reflect official positions of De Nederlandsche Bank nor of the Eurosystem of central banks. 


\section{Introduction}

An extensive literature has not only shown that natural resources can exacerbate challenges of macroeconomic management, but points to a fundamental problem faced by producers of natural resources: how to transform subsoil wealth into productive assets such as financial, human and physical capital (van der Ploeg and Venables, 2012). The need to absorb windfalls gains and manage them appropriately has been discussed extensively by academics and policy makers alike.

An equally large literature has shown the importance of the financial system for economic development. One of its primary functions is to intermediate domestic savings into domestic investment. The financial system should thus serve as an important absorption tool for windfall gains, such as arising from natural resource rents. While a recent literature has explored the importance of financial development for fiscal policy space ${ }^{1}$, monetary policy transmission $^{2}$ and exchange rate choice ${ }^{3}$, there is a limited literature on the effectiveness of the financial system in absorbing and intermediating natural resource rents. A limited role for the financial sector may lead to inefficient investment, waste of resources, amplified business cycles, and poor intertemporal allocation. This is may be especially relevant in the many capital-scarce developing countries that specialize in natural resource extraction, which also tend to have small financial sectors and weaker governance.

This paper gauges whether natural resource windfalls are associated with changes in financial sector deposits and lending, using a panel dataset of over 150 developed and developing countries over the period 1970 to 2008, covering a period of high commodity price volatility. While previous papers have shown a negative relationship between natural resource abundance and financial sector development (Beck, 2011; Bhattacharya and Hodler, 2014), endogeneity challenges have prevented researchers from drawing causal inferences. We address endogeneity by relating changes in domestic sector lending and deposit taking by the financial system to exogenous changes in natural resource rents. Specifically, we develop a novel methodology to isolate windfalls arising from unexpected and exogenous world price changes that affect a country's effective natural resource export price from those arising from increased production or from reduced unit production costs. By focusing on unexpected changes in prices and applying structural VAR methods, we address identification concerns related to cross-country explorations of the relationship between natural resources and financial

\footnotetext{
${ }^{1}$ See Caballero and Krishnamurthy (2004).

${ }^{2}$ See Mishra et al. (2012)

${ }^{3}$ See Aghion et al. (2006)
} 
development. Specifically, by observing on a high-frequency basis the adjustment of financial system indicators to changes in a country's natural resource rents, it is easier to control for other unobserved country-level factors. Similarly, by focusing on the price component in the resource change, we better control for endogeneity, as price changes are all but outside the control of individual countries.

Theory makes contradictory predictions on the relationship between changes in natural resource rents and financial sector lending and deposits. On the deposit and funding side, higher natural resource rents can result in higher deposits for a country's banking system if they are saved domestically. On the other hand, windfall gains can also lead to a shift of wealth out of the domestic financial system, either into foreign investment conduits and offshore sovereign wealth funds, or into non-financial wealth, especially in the case of inefficient financial sectors. ${ }^{4}$ On the lending side, windfall gains from natural resources, higher incomes and the consequent expansion of the non-traded goods sector can lead to higher private demand for financial services, including consumer credit. Moreover, there is evidence that natural resource booms lower constraints to international borrowing by increasing collateral and raise public demand for loans (Mansoorian, 1991; Manzano and Rigobon, 2007). On the other hand, the traded sector might suffer as natural resource rents lead to more resource extraction, crowding out of the non-resource sector ${ }^{5}$ and thus resulting in lower demand for external finance. Finally, windfall gains or losses may have asymmetric effects on the financial system.

Controlling for the level of financial development, inflation, GDP growth and country fixed-effects, we find a relative decline in the volume of financial sector deposits in countries that experience an unexpected natural resource windfall. While we find that financial system deposits tend to increase following the windfall - which is the optimal response to a transitory shock - comparing countries with similarly booming economies as captured by total GDP growth, we find that those countries where the boom is induced by an unexpected positive shock to the exogenous world price of its basket of natural resources experience a relative decline in private financial sector deposits. Moreover, we find that the relative volume of private sector lending also declines, although the decline in lending is mostly due to the

\footnotetext{
${ }^{4}$ The normative approach to how a country should consume or invest a resource windfall is described in detail in van der Ploeg and Venables (2012, 2013). Based on the permanent income hypothesis, they conclude that windfall revenue should be saved abroad at a level that smooths consumption over time. If future revenues are uncertain then additional savings in a stabilization or sovereign wealth fund are warranted. However, capital scarce developing countries should consider public investment, a reduction in distortionary taxation, and using windfall revenue to relax foreign borrowing constraints and thus saving less abroad.

${ }^{5}$ As predicted by standard models of Dutch disease. See for example Neary (1988) and Corden and Neary (1982).
} 
decrease in deposits. ${ }^{6}$ The smaller role for the financial sector in intermediating the mineral boom may be a reason why the quality of investment decisions decreases (as proxied by an increase in the share of non-performing loans) and may help to explain why natural resource rents tend be associated with slow aggregate growth in countries with less developed (financial) institutions. These country level results hold across different types of deposits, they are confirmed with bank-level regressions and independently of bank characteristics, are robust to controlling for news about natural resource discoveries, to dropping major mineral exporters, and to the existence of sovereign wealth funds. In addition, we find evidence that foreign assets and government deposits with commercial and central banks increase following a natural resource price shock. We also find that the higher government deposits with commercial and central banks results in higher government consumption, but this in turn does not lead to more private lending. Our results are not only statistically but also economically significant. Compared to the counterfactual of a country growing at similar speed, a doubling of commodity price inflation induces a relative decline of deposit growth by $3.4 \%$, but increases relative growth of foreign assets by $9.6 \%$ and government deposits with central banks by $19.3 \%$, which in turn raises government consumption but not private lending. Overall, our findings are consistent with the negative long-term relationship between the reliance of a country on natural resources and financial sector development as well as the government as major beneficiary of natural resource booms while at the same time undermining the financial intermediation process. We also find important cross-country variation in that our findings hold primarily for countries with less developed institutional frameworks and repressed financial systems. On the other hand, we do not find asymmetry between increases and decreases in natural resource rents in their effect on financial sector deposits and lending.

Our paper adds to several literatures. First, we add to the literature on finance and growth. An expansive literature has shown the positive relationship between financial development and economic growth (see Levine, 2005, for an overview). There is also evidence that countries with better developed financial systems suffer less economic volatility and that well-developed financial systems can mitigate the impact of real sector shocks (Beck et al., 2006). While the recent literature has shown the non-linearity between financial development and economic growth (e.g. Arcand et al., 2015), there is evidence that natural resource based economies benefit at least as much from a well-developed financial system as non-resource economies (Beck, 2011). We add to this literature by focusing on the effect of exogenous

\footnotetext{
${ }^{6}$ Starting from the view that loans create deposits, rather than the other way around, we find similar results.
} 
changes in natural resource rents on changes in financial system lending and deposits. Our results show the limited role of domestic financial sectors in absorbing and intermediating windfall gains from natural resource rents. Moreover, we relate to the debate on whether capital inflows are expansionary, because they lead to credit booms and rising output, or contractionary, through the appreciation of the currency. Blanchard et al. (2015) suggest that only non-bond flows are expansionary because they reduce the cost of borrowing. We find that non-bond capital inflows that are associated with natural resource windfalls tend to be only partially intermediated and may thus not decrease the cost of borrowing much. Rather, the expansionary pressure may come from non-intermediated investment, such as higher government consumption.

Second, we add to the literature on the determinants of financial development. While a large literature has focused on macroeconomic stability and the institutional framework underpinning financial transactions, using regression analysis with data averaged over longer time periods, we focus on the short-term association of variation of financial system lending and funding with short-term variation in natural resource rents. ${ }^{7}$ Our paper adds to this literature by showing that windfall gains from natural resource rents are associated with reductions in deposit-taking and lending by banks and thus undermine financial sector development in natural resource rich societies.

Third, we add to the literature on natural resource rents (see van der Ploeg, 2011, for a recent survey). Mostly, this literature has focused on the relationship between natural resource dependence and national income growth and the reasons behind poor outcomes. For example, van der Ploeg and Poelhekke (2009ab) and Bhattacharya and Hodler (2014) find respectively that natural resource dependence can be a drag on economic growth by increasing macroeconomic volatility, which can be mitigated by more developed financial systems, but that low financial development itself may be a result of poor contract enforcement in resourcerich countries with weak political institutions. Furthermore, van der Ploeg and Venables (2012) explore several reasons why most countries are unable to turn natural resource wealth into optimal investment strategies. ${ }^{8}$ However, they discuss the domestic financial sector mostly

\footnotetext{
${ }^{7}$ This is also different from Bhattacharya and Hodler (2014) who relate the level of natural resource rents as a share of GDP to the level of financial development (private credit over GDP), with both averaged over five-year periods. They instrument rents over GDP with a country-specific price index of commodities. However, in our view, prices have direct effects on the financial system, for example by changing the value of collateral and the net present value of investment opportunities. When measuring financial development as bank deposits over GDP as a robustness exercise, they find a negative relationship significant at the $10 \%$ confidence level.

${ }^{8}$ Van der Ploeg and Venables highlight issues of political economy such as weak fiscal discipline in combination with powerful lobbying for public funds leading to unproductive public spending (Tornell and Lane, 1999) and expropriation by incumbent rulers (Acemoglu et al., 2004); macroeconomic volatility and boom-bust cycles (van
} 
indirectly and only in so far as private saving decisions are altered. ${ }^{9}$ This paper adds to this literature by investigating how windfall income affects the funding of banks and their lending behavior. Adverse effects of nature resource production induced windfall income on the ability of the financial sector to intermediate capital may seriously constrain countries in their goal of achieving sustainable growth. One reason to worry is that unrestrained direct spending by governments all too often leads to unproductive projects, especially in developing countries with lower quality governance (Bates, 1981; Robinson and Torvik, 2005; Afonso et al., 2010).

The remainder of the paper is organized as follows. The next section presents our indicators of natural resource rents and financial sector development. Section 3 discusses the methodology and section 4 presents the main results. Section 5 offers a series of robustness tests and section 6 concludes.

\section{Data}

To test the relationship between financial deepening and natural resource windfalls, we use data for a broad cross-section of countries over the period 1971 to 2008, covering a period of high commodity price volatility (Jacks, 2013). ${ }^{10}$ This section describes the different data sources and variables. Appendix Table A1 reports descriptive statistics, definition, and source for each of the variables.

\subsection{Natural resource rents}

The literature has used different indicators to measure the reliance of economies on natural resources, ranging from the export share of natural resources in total exports to the importance of sub-soil wealth in a country's total wealth and giant oil field discoveries. In cross-country growth regressions on the long run impact of natural resource wealth these have been criticized for their lack of exogeneity as they are based not only on exogenous geology, but also on exploration effort, technology and extraction costs (and thus growth and institutions) that determine the degree of economic recoverability of resources (see for example the discussion in van der Ploeg and Poelhekke, 2010). Recently, also the likelihood of giant oil

der Ploeg and Poelhekke, 2009a) which calls for making more use of hedging, stabilization funds, and better macroeconomic management. There is also evidence that corruption increases after sudden windfalls (Svensson, 2000; Vincente, 2010) and that natural resource wealth can undermine institutional development (Beck and Laeven, 2006).

${ }^{9}$ These may change if resource wealth reaches citizens through handouts, subsidies or tax reductions; if the government reduces domestic debt or lends directly to the private sector through development banks; or if expectations on future taxes are changed.

${ }^{10}$ Our sample period is constrained by the availability of data on natural resource windfalls as discussed below. 
and gas field discoveries have been shown to depend on the quality of institutions, because exploration effort relies on the quality of institutions (Tsui, 2011; Arezki et al., 2016).

To credibly isolate an exogenous shock, we need to disentangle windfalls due to exogenous world price shocks from changes in natural resource revenues due to less exogenous changes in quantities produced or extraction costs. Our main variable to test the effect of natural resource windfalls on an economy is therefore based on the World Bank (2011) data set on resource rents, which is defined as revenue net of extraction costs for the total of metals and mineral produced (including oil, gas, coal, bauxite, copper, lead, nickel, phosphate, tin, zinc, gold, silver, and iron ore) and is available up to $2008 .{ }^{11}$ It is computed as total production times the world price net of unit cost of production. ${ }^{12}$ There is a wide variation in our sample for total natural resource rents, ranging from zero to $116.5 \%$ of GDP. The log changes in total rents range from $-627 \%$ to $546 \%$, with a mean of $12 \%$, suggesting substantial shocks to these economies. However, to identify the relationship between natural resource windfalls and changes in financial sector deposits and lending, we introduce a novel methodology to the natural resource literature and split the resource rents into its components.

Specifically, we split the log change of resource rents into (i) the log change in the Paasche price index ${ }^{13}$ of metals and minerals, with base year 1970, to capture windfalls due to exogenous world price shocks, (ii) the log change in metal and minerals revenue (value of production) divided by the Paasche price index of metals and minerals ${ }^{14}$, which indexes windfalls due to changes in production, and (iii) the log change in Paasche unit production cost index of metals and minerals, with base year 1970. Most closely related to the concept of a

\footnotetext{
${ }^{11}$ Available here: http://siteresources.worldbank.org/EXTEEI/Resources/Metals_and_Minerals_Rents.xls; http://siteresources.worldbank.org/EXTEEI/Resources/oil_and_gas_rents.xls; http://siteresources.worldbank.org/EXTEEI/Resources/Hard_Coal_and_Lignite_Rents.xls. More recent versions of the data no longer split minerals and no longer separate prices from production and unit costs.

${ }^{12}$ The unit cost estimates are best for major producers, but partly imputed for other countries. If data for a single year was available, it was assumed that production costs remained constant in real terms using the US GDP deflator. Missing data between two different years with data were linearly interpolated. If no data was available then geographic proximity and similarity between the ratios of offshore active drilling rigs to total active drilling rigs between the two countries were used. See Bolt et al. (2002) for more details on the construction of unit costs. For this reason, we will always control for (changes in) unit costs but we do not interpret its coefficients.

${ }^{13}$ The Paasche price index for several different minerals $c$ is defined as

$$
P=\sum_{c} p_{c t} q_{c t} / \sum_{c} p_{c, t=0} q_{c t}
$$

The $\log$ first difference of this index for one good $c$ is equivalent to the rate of inflation in good $c$. For multiple goods, it tracks the overall export price level faced by a country that produces a basket of goods. We choose the Paasche price index instead of a Laspeyres index that relies on base year quantities, because base year prices of all resources are known, while not all resources are produced in each country in base year 1970. In Table 11 we experiment with alternative chained indices with lagged weights and show that our results are robust.

${ }^{14}$ We do not include quantities produced directly to facilitate summation over various units such as barrels of oil, cubic feet of natural gas and tons of metals.
} 
windfall is the change in the country- and year-specific price index. A change in the world price of, for example oil, will only translate into a substantial windfall in those countries that produce a lot of oil. This is captured by the country-year-specific price index, which allows for mineral weights that are different for each country-year. By keeping changes in quantities and unit costs constant in the regressions, we can isolate the exogenous effect of a natural resource windfall induced by world price shocks. A windfall may also occur for given prices if new discoveries come into production. This is captured by the quantity index, although this source of windfall gain is less unexpected than a price-driven windfall and may be factored into fiscal policy. Also, a change in quantity produced may be the direct result of historical or expected price changes. Lastly, a windfall may occur through a drop in the production costs of resources. The average price shock is $7.7 \%$ of GDP, while quantities change on average by $2.8 \%$ per country-year. ${ }^{15}$ The average change in cost is $5.8 \%$. Appendix Table A2 shows the correlation between changes in mineral rents and its components. We see that price shocks are by far the most important component as an one percentage point change in prices leads to more than twice as high a change in rents as an one percentage point increase in quantity and almost four times as high a change in rents as an one percentage point reduction in costs. Focusing on price changes thus not only allows us to isolate the exogenous component of changes in rents but also capture the economically most important component.

\subsection{Financial development indicators}

We use several standard indicators of financial sector development, used by the financial development literature over the past two decades. First, we use an indicator of domestic sector lending, notable Private Credit to GDP, a standard indicator of total lending by financial institutions to non-financial domestic private households and enterprises, normalized by economic activity. Later, we measure private lending as the volume of private credit and separately control for GDP. We also use an indicator of bank lending to central and local governments and to state-owned enterprises. Natural resource rents might lead to an easing on funding pressures by governments and government-owned enterprises if they can

\footnotetext{
${ }^{15}$ Others have also used price indices to measure natural resource shocks such as Deaton and Miller (1996), Bazzi and Blattman (2014) and Harding and Venables (2016). However, they have used as weights the export volume by resource and country, with export shares often fixed to one base year. We believe however that the volume of production is more relevant since trade shares will underestimate resource booms that are (partly) consumed domestically, such as the recent shale gas boom in the United States. Moreover, we control for the change in quantity produced to separate relatively endogenous quantity-induced windfalls from exogenous price-induced windfalls. Finally, using only one base year will miss booms occurring though discoveries made after the base year.
} 
rely on the higher income stemming from natural resource revenues. Alternatively, the pressure on banks to lend to governments and their enterprises might increase if higher natural resource revenues translate into higher political power.

Second, we use several indicators of deposits in the financial system, all taken from the IMF's International Financial Statistics, unless stated otherwise. Specifically, we focus on deposits by the (i) total financial system, including banks and non-bank financial institutions and (ii) banking system deposits. We also consider different sources of deposits. Specifically, we distinguish between (i) government deposits with central banks and (ii) government deposits with commercial banks ${ }^{16}$ to investigate whether additional resource revenues result in more net savings by the government in the form of banking system deposits. Following previous research, we also use offshore bank deposits, i.e. the amount of deposits relative to GDP held outside the economy, based on data from the BIS. Previous research has shown a relationship between resource rents and off-shore bank deposits, especially in tax havens (Andersen et al., 2017). We also use net foreign assets by commerical banks to test whether changes in resource rents are associated with higher funding of banks from abroad or higher investment by banks abroad.

In addition to aggregate indicators of financial development, we also use bank-level data from Bureau van Dijk's BankScope data set. Unlike the aggregate cross-country data, the timespan for these data is limited to 1987 to 2008. We use loan growth and deposit growth of banks and control for several bank characteristics in our analysis. We also interact changes in natural resource rents with specific bank characteristics to explore whether the relationship varies across banks.

\subsection{Macro-indicators}

In addition to financial system and bank indicators, we also explore the relationship between changes in natural resource rents and macroeconomic aggregates, including consumption and savings, taken from the World Bank's World Development Indicators, and gross assets and liabilities form Lane and Milesi-Ferretti (2007). Specifically, we consider the relationship between changes in natural resource rents and changes in gross domestic savings, household and non-household financial consumption and central government consumption. In robustness tests, we also control for the level of institutional development, with data from the

\footnotetext{
${ }^{16}$ We use the name "commercial bank" synonomous with the term "deposit money bank" as used by the International Financial Statistics.
} 
International Country Risk Guide (ICRG) and the financial liberalization database, put together by Abiad et al. (2008).

\section{Methodology}

We relate changes in the three components of natural resource rents to changes in financial sector development in dynamic panel regressions that use annual observations over the period 1971 to 2008 for up to 156 countries. Specifically, we use the following regression set-up

$$
\Delta F_{i t}=\alpha \Delta F_{i, t-1}+\beta_{1} \Delta P_{i t}+\beta_{2} \Delta Q_{i t}+\beta_{3} \Delta U C_{i t}+\gamma \Delta X_{i t}+\delta Z_{i t}+c_{i}+\varepsilon_{i t}
$$

where $F$ is one of our financial development indicators or macro-aggregates, $P$ is the natural resource price index, $Q$ the natural resource quantity index, $U C$ the natural resource unit cost index, $\Delta X$ and $Z$ are arrays of control variables, $i$ denotes country and $t$ year. We include country $\left(c_{i}\right)$ fixed effects. Our coefficient estimates thus capture within-country variation: rather than focusing on cross-country relationships, we gauge how a change in natural resource rents within a country relates to changes in financial sector development within this country. As changes in financial sector development might be persistent, we include the lagged dependent variable and cluster standard errors on the country-level, thus allowing arbitrary heteroskedasticity and for correlations of error terms within but not across countries. ${ }^{17}$ First differencing also ensures that the model is stationary. The matrix $X$ always includes the rate of inflation since all variables are measured in nominal terms. In matrix $\mathrm{Z}$ we also control for initial (predetermined) financial development. In time-series terminology, this model is an autoregressive-distributed lag representation of an infinite distributed lag model, and assumes that the weights on additional lags decline at the same rate for each variable. In other words, $\Delta F_{i t}$ reacts equally quickly to each right-hand-side variable. The short run effect of each variable is its coefficient, while the long run cumulative effect of a permanent shock is the coefficient divided by one minus the coefficient of the lagged dependent variable, $\alpha{ }^{18}$

\footnotetext{
${ }^{17}$ Results are robust to allowing for two-way clustering on both countries and years, which includes arbitrary cross-sectional spatial dependence.

${ }^{18}$ In short panels, the correlation between the fixed effects and the error term introduces a downward bias in the parameter $\alpha$, and an upward bias if the fixed effects are excluded. However, the bias goes to zero as the time dimension approaches infinity, see Nickell (1981). In our case, T typically equals 38, which, in combination
} 
Next, we relax this assumption of a common decline rate and estimate a 'rational autoregressive-distributed lag model' which includes a lagged dependent variable and lags of right-hand-side variables and estimate a fully dynamic reduced-form vector autoregressive (VAR) model (Lütkepohl, 2006):

$$
\begin{aligned}
\Delta Y_{i t}= & A^{-1} B_{01} \Delta Y_{i t-1}+\sum_{j=0}^{4} A^{-1} B_{1 j} \Delta P_{i t-j}+\sum_{j=0}^{4} A^{-1} B_{2 j} \Delta Q_{i t-j}+ \\
& \sum_{j=0}^{4} A^{-1} B_{3 j} \Delta U C_{i t-j}+A^{-1} D Z_{i t-5}+A^{-1} C_{i}+A^{-1} \varepsilon_{i t}
\end{aligned}
$$

where $\Delta Y_{i t}=\left(\Delta F_{i t}, \Delta G D P_{i t}, \pi_{i t}\right)^{\prime} \cdot A^{-1} B_{01}, A^{-1} B_{k j}, k \in[1,2,3]$, and $A^{-1} D$ are $3 \times 3$ matrices of parameters to be estimated. GDP is taken from the World Bank's World Development Indicators and $\pi$ is the log difference of its deflator. All other right-hand-side variables affect all three dependent variables. The minimum lag order is chosen such that there is no remaining autocorrelation in the error term and insignificant trailing lags are dropped to maximize power.

Finally, we estimate a structural vector autoregressive (SVAR) model by multiplying the above model by a matrix A. As is standard in the VAR literature, this model can be estimated and identified by assuming a causal ordering of the three endogenous variables included in $\Delta Y_{i t}$. We assume that $A=\left[\begin{array}{lll}1 & \cdot & \cdot \\ 0 & 1 & \cdot \\ 0 & 0 & 1\end{array}\right]$, where the ['] are parameters to be estimated. This means that both GDP and inflation are allowed to influence deposits contemporaneously, to ensure that we estimate the effect of a windfall on a measure of financial development relative to GDP's effect on the demand for financial services. Inflation may also move nominal GDP simultaneously, but we assume that deposits affect GDP and inflation only with a delay. Since deposits are equal to income saved for future spending, we believe this assumption is justified. $^{19}$

We estimate the baseline VAR and SVAR with iterated seemingly unrelated regression (based on feasible generalized least squares) to allow the error terms to be correlated and

\footnotetext{
with the fact that the estimate of $\alpha$ with and without fixed effects is very close suggests that the bias is minor (Bond, 2002). We perform Arellano-Bond GMM estimates as a robustness check (Arellano and Bond, 1991). ${ }^{19}$ Because matrix A is lower-triangular this is equivalent to a recursive VAR and we do not overidentify the SVAR.
} 
perform a bootstrap to generate standard errors, where we resample from within each country. However, because the models are nested the estimates collapse to OLS and we can also cluster the standard errors by country. As a robustness check we perform Arellano-Bond GMM estimates which instrument the endogenous variables with their lagged levels (Arellano and Bond, 1991). The baseline specification is thus:

$$
\begin{gathered}
\Delta F_{i t}=\alpha_{1} \Delta F_{i, t-1}+\sum_{j=0}^{4} \beta_{1 j} \Delta P_{i t-j}+\sum_{j=0}^{4} \beta_{2 j} \Delta Q_{i t-j}+\sum_{j=0}^{4} \beta_{3 j} \Delta U C_{i t-j} \\
+\Gamma_{0} \Delta X_{i t}+\Gamma_{1} \Delta X_{i, t-1}+\delta Z_{i t-5}+c_{i}+\varepsilon_{i t}
\end{gathered}
$$

where $\Delta X_{i t}=\left(\Delta G D P_{i t}, \pi_{i t}\right)^{\prime}$ and $\Gamma_{j}$ are $1 \times 2$ matrices of parameters.

Our main parameters of interest are the $\beta_{1 j}$. The short run elasticity of each variable is its coefficient, while the long run cumulative effect of a permanent shock is the (sum of the lagged) coefficient(s) divided by one minus the coefficient of the lagged dependent variable. For example, a one unit permanent increase in $\Delta P$ leads to a $\left(\sum_{j=0}^{4} \beta_{1 j}\right) /\left(1-\alpha_{1}\right)$ unit change in $\Delta F$. However, because real commodity prices trend upwards in levels (Jacks, 2013) we first difference the data to make them stationary and focus on the short run effects of a shock to the annual change in natural resource prices, which tend to be relatively transitory. We run similar regressions for different measures of deposits and drop insignificant trailing lags of right-handside variables. When the left-hand-side is a measure of lending, we include deposits as a fourth endogenous variable and add lending to the front of the causal ordering. ${ }^{20}$

We also estimate this relationship at the bank-level, where the dependent variable is loan growth or deposit growth by bank $j$ in country $i$ and year $t$. In these regressions, we also interact the changes in natural resource shocks with bank characteristics to gauge whether the relationship between resource shocks and lending growth varies across banks with different characteristics. We will describe the regression set-up below.

\section{Results}

We start our empirical analysis with a regression of the level of natural resource rents on the level of financial system deposits and lending to replicate results that were previously established in the literature.

${ }^{20}$ In Section 4.3 we explore the robustness to an alternative ordering. 
The results in Table 1 confirm previous results that higher natural resource rents are associated with lower levels of financial development, even when controlling for the level of GDP per capita and an indicator of institutional development. The regressions control for country and year fixed effects, with standard errors clustered on the country level; thus, we are exploiting within-country and within-year variation in natural resource rents and financial development. The results hold for both the lending side of financial development (columns 1 and 2) as for the deposit-taking side (column 3). We also find a negative relationship between natural resource rents and the loan-deposit ratio in the banking system (column 4). The effects are not only statistically significant, but also economically meaningful. A one standard deviation in resource rents explains 8.6 percentage points different in Private Credit to GDP, 4.9 percentage points difference in Bank Deposits to GDP and 14.8 percentage points difference in the loan-deposit ratio, even after controlling for GDP per capita.

While these results are consistent with the previous literature, they do not control for endogeneity, as the share of mineral rents in GDP is not exogenous. We therefore split resource rents into its components and investigate year to year changes from now on. Before doing so, however, we first assess the relationship between changes in the components of natural resource rents and macroeconomic aggregates, to establish the aggregate effects of windfall gains as backdrop for the role of the financial sector in such aggregate effects.

\subsection{Natural resource windfalls and macroeconomic effects}

The results in Table 2, columns 1-5 show that a sudden windfall as measured by a year to year change in the value of the mineral price index is positively associated with growth in total foreign gross assets (column 1), aggregate savings (column 2), household and nonhousehold consumption (columns 3 and 4) and government consumption (column 5). Specifically, a $1 \%$ windfall leads to a $0.1 \%$ increase in foreign gross assets. This effect is net of revaluation of the dollar value of local currency assets induced by an appreciation of the real exchange rate. ${ }^{21} \mathrm{~A} 1 \%$ windfall also leads to a $0.4 \%$ increase in gross domestic savings and a $0.1 \%$ increase in household and in non-household consumption. Finally, a 1\% windfall gain due to price increases results in $0.1 \%$ increase in the volume of government consumption. These findings are in line with the theoretical optimal response to an unexpected windfall increase in income, as they are partially saved to smooth consumption (Van der Ploeg and

\footnotetext{
${ }^{21}$ Real appreciation is measured as an increase in the log change in the price level of GDP relative to the US price level of GDP, with base year 2005, taken from the Penn World Tables 8.1.
} 
Venables, 2012). As we include the lagged dependent variable, we are able to also compute the long-term effects of shocks to natural resource rents, by considering the ratio of the coefficient on price shocks and one minus the coefficient on the lagged dependent variable. We do not find that the long-term effect is much different from the short-term effect in most cases.

In column 6 , we also find that a year to year change in the value of the mineral price index is associated with an increase in the volume of financial system deposits. While this result might seem surprising in the light of the negative correlation between natural resource rents and financial development found in Table 1, the positive relationship between resource prices and deposits can be explained by the increase in GDP following resource windfalls. When we add non-mineral GDP in column 7, the coefficient on natural resource price changes turns insignificant, while the coefficient on non-mineral GDP is positive and significant. When we finally add the change in total GDP in column 8 we find that price induced windfalls predict a relative decline in financial system deposits. The results suggest that an increase in GDP leads to more deposits, but when comparing the effect of an average change in GDP to the effect of a similarly sized change in GDP that is due to an unexpected mineral windfall, we find that windfalls predict a relative crowding out of financial system deposits. This is a novel finding in the literature, which we will explore further in the following. While the short-term effect of a $1 \%$ price shock is a $-0.06 \%$ relative decline in financial system deposits, the long-term effect is $-0.08 \%$, thus somewhat stronger. The effect of an average price shock of $7.7 \%$ is thus a $0.6 \%$ decrease in deposits.

The negative relationship between changes in natural resource rents and deposits is mostly driven by price changes. While the change in natural resource quantity (due to a new discovery or expansion of production) enters negatively and significantly once we control for changes in non-mineral GDP or overall GDP, we find that a change in unit cost is positively associated with deposit volume, but significantly only as long as we do not control for GDP changes. We do not report these coefficients to save space, although they are always included.

In summary, the initial aggregate regressions suggest that the higher savings from natural resource windfalls are not saved through the financial system. In the following, we will explore the links between windfall gains and financial sector deposits and loans in more detail.

\subsection{Natural resource windfalls and the relative decline in private sector deposits}

The results in Table 3 confirm our findings of a negative association of windfall gains from natural resource rents and reductions in financial system deposits and present evidence 
for a crowding out of deposits in favor of foreign asset-holdings. In Panel A, we first present a VAR model of order 1, with three endogenous variables, namely growth of financial system deposits, GDP growth and inflation. Compared to the Table 2 regressions, we now also include the lag of both the dependent and of the other endogeneous variables, as well as several lags of the price, quantity and cost change variable of natural resource rents, thus relaxing the assumption of a common decline rate and estimating a 'rational autoregressive-distributed lag model'. We estimate the model with iterated seemingly unrelated regression (based on feasible generalized least squares) to allow the error terms to be correlated and perform a bootstrap to generate standard errors, where we resample from within each country.

The results in column (1) show that a natural resource windfall raises deposits on impact and the effect decays slowly over time, with short-term effect of a $1 \%$ price shock of $0.08 \%{ }^{22}$ The column (2) results show that such a price shock also raises GDP growth with twice the magnitude, though it is less persistent. We also find a positive impact of the price shock on inflation, an effect that is very persistent through the higher coefficient on lagged inflation (column 3). The twice as high impact of the price shock on GDP growth than on growth of financial system deposits is consistent with the finding of Table 2 that relatively less is saved in private accounts than one would expect from normal GDP growth on impact. The results in columns (4) to (8) show the corresponding finding for the growth of bank deposits, offshore bank deposits, growth in foreign assets (in banking institutions) and growth in government deposits with commercial banks and with the central bank. ${ }^{23} \mathrm{We}$ find similarly positive and significant effects as for the case of growth in financial system deposits, although a substantial variation in economic significance. Specifically, we find a much stronger effect of the price shock on growth in foreign assets than on growth in bank deposits and an even larger impact on growth in government deposits with the central bank. Offshore bank deposits do not change immediately, but respond strongly and positively after a delay of two to four years.

We next move to a structural VAR (SVAR) model, imposing the assumption that both GDP and inflation can influence deposits contemporaneously, that inflation may also move nominal GDP simultaneously, but that deposits affect GDP and inflation only with a delay. In terms of equation (2), we assume that matrix $A$ is lower triangular and that $\Delta Y_{i t}=$ $\left(\Delta F_{i t}, \Delta G D P_{i t}, \pi_{i t}\right)^{\prime}$. Panel B of Table 3 shows the results. Compared to the VAR model in columns (1) to (3) of Panel A, we thus include contemporaneous GDP growth and inflation in

\footnotetext{
${ }^{22}$ If the shock to the commodity price inflation would be permanent the long-term cumulative effect would be $0.36 \%=(0.078+0.067+0.043+0.044) /(1-0.354)$.

${ }^{23}$ For conciseness, we do not report the GDP growth and inflation regressions for these results.
} 
the regression of growth in financial system deposits (column 9) and the inflation rate in the GDP growth regression (column 10) The regressions confirm that a positive price shock results in a relative decrease in the volume of deposits (column 9) and an increase in GDP and inflation (columns 10 and 11). ${ }^{24} \mathrm{We}$ also find a strong positive contemporaneous relationship between GDP growth and growth in financial systems deposits, confirming that higher GDP growth also increases growth in financial system deposits, unless higher GDP growth is caused by a natural resource price shock. Compared to the counterfactual of a country growing at similar speed, a doubling of commodity price inflation induces a relative decline of deposit growth by $3.4 \%$. Considering different categories of deposits, we find that bank deposits decrease significantly, while foreign assets increase significantly with a windfall gain due to a price increase, as do government deposits with central banks, while government deposits with commercial banks do not change significantly (columns 12 to 16). Offshore deposits initially decrease, but insignificantly, while they significantly increase with a delay.

We also tested, but rejected, asymmetric effects by splitting price shocks into positive and negative shocks. Positive and negative shocks were never of significant different magnitude (results not reported to save space, but available on request).

In Table 4 we examine how the higher governments deposits are being used. Specifically, we regress the growth in government consumption and in private sector lending on contemporaneous and lagged growth in government deposits with commercial and central banks, on contemporaneous and lagged growth foreign asset holding, on contemporaneous and lagged growth in private sector deposits (only in column 2), the lagged dependent variable, financial development, contemporaneous and lagged inflation and (in column 2) contemporaneous and lagged growth. We find a strongly positive and significant impact of growth in government deposits with commercial and central banks on growth in government consumption and a contemporaneous (though smaller) impact of growth in government deposits with commercial banks on growth in private sector lending. We also find (not surprising) a positive impact of contemporaneous and lagged growth in private sector deposits on growth in private sector lending, but no effect of growth in foreign assets holding on either growth in government consumption or private sector lending.

Overall, the findings in Table 3 point to windfall gains from positive natural resource shocks accruing to government coffers, being held primarily with central banks and or in the

\footnotetext{
${ }^{24} \mathrm{We}$ confirm the negative coefficient on financial system deposits when dropping several lagged values of the mineral price, quantity and costs variables that do not enter significantly, as well when using the Arrellano and Bond (1991) difference GMM estimator.
} 
form of foreign assets. Ultimately, (as shown in Table 4) part of the higher windfall gains held in government deposits with commercial and central banks find their way into higher government consumption. While private deposits (by enterprises and households) do increase after a price shock due to higher GDP, this gain is substantially smaller than under comparable increases in GDP due to non-resource shocks. Ultimately, this points to the financial system being by-passed when it comes to growth enhancing natural resource shocks and is consistent with the results in Table 1 of lower financial intermediation following resource shocks and the larger literature documenting less developed financial systems in resource-rich countries. While so far we have focused mostly on the liability side of banks' balance sheet, we now turn to the asset side.

\subsection{Natural resource windfalls and the relative decline in private credit}

Does the decline in deposits translate into a decline in lending by banks? To answer this question, we now turn to regressions where the dependent variable is the log change in private credit. As before we first present simple regressions before turning to a structural VAR model. The results are presented in Table 5. Unlike before, we now work with 4 endogenous variables: private sector lending, private sector deposits, GDP, and inflation.

The VAR results in columns (1) to (3) of Panel A show an increase in bank lending to the private sector following a natural resource price shock. First, we find in column (1) that windfalls are associated with increases in lending. However, most of this increase in lending is due to the change in deposits: adding the change in deposits in column (2) almost halves the effect of the windfall. The fact that the coefficient is below one, however, suggests that an increase in deposit funding is not completely passed into new lending. The effect is further reduced when we include the change in non-mineral GDP in column (3). In columns (4) to (7), finally, we run a SVAR model with private sector lending, private sector deposits, GDP, and inflation. We impose the same structural assumption as before and in addition assume that growth in financial system deposits, GDP growth and inflation can impact private sector lending growth, while private sector lending growth cannot impact any of the other three variables contemporaneously, but only through lags. In terms of equation (2), we again assume that matrix $A$ is lower triangular but $4 \times 4$ and that $\Delta Y_{i t}=$ $\left(\Delta \text { Lending }_{i t}, \Delta \text { Deposits }_{i t}, \Delta G D P_{i t}, \pi_{i t}\right)^{\prime}$. We find no significant impact of natural resource price shocks on private sector lending growth, positive and significant effects on GDP growth and inflation and (on impact) a negative and significant effect on growth in financial system deposits. A doubling of commodity price inflation reduces deposit growth by $3.7 \%$ and thus 
indirectly lending growth by $0.037 * 0.254=0.9 \%$. We also find a positive and significant contemporaneous impact of growth in financial system deposits and GDP growth on private sector lending growth and a negative contemporaneous effect of inflation. Similar to the effect on deposits, we thus find that when comparing countries with similarly booming economies as captured by total GDP growth, that those countries where the boom is induced by an unexpected positive shock to the exogenous world price of its basket of minerals do not experience an increase in lending and, if at all, a decrease. We conclude that an increase in natural resource wealth appears to crowd out financial intermediation by banks, mainly by reducing deposits.

In Panel B of Tale 5 we impose an alternative structural assumption on the SVAR. Specifically, in line with the few that it is lending that creates deposits, we assume that lending growth, GDP growth and inflation can impact growth in financial sector deposits, while growth in financial sector growth can impact any of the other three only through lags but not contemporaneously. ${ }^{25}$ Our results are very similar to the results in Panel A, with a negative contemporaneous effect of price shocks on deposits and a positive lagged effect. There is no significant effect of price changes on private sector lending, except for a positive effect in the fourth lag. As before, we find positive relationships between deposit and lending growth. Overall, imposing an alternative structural assumption does not change our main conclusion of a crowding out of financial intermediation by banks following an exogenous increase in natural resource wealth.

When considering (in Panel $\mathrm{C}$ using our baseline ordering of variables) lending to the central government, state and local governments, and public companies, we find no significant effects, although these samples are also much smaller (columns 12-14). ${ }^{26}$ So far, we have focused on domestic lending. In columns (15) to (17) we investigate the foreign borrowing position of countries as a whole in the spirit of Manzano and Rigobon (2007) who highlight the issue of debt overhang: when commodity prices are high it becomes easier to borrow which may lead to debt crises once commodity come down. In columns (15) and (16) we therefore regress the change in log total gross liabilities from Lane and Milesi-Ferretti (2007) and national gross debt liabilities on our measure of windfall booms. National borrowing increases

\footnotetext{
${ }^{25}$ This is consistent with recent research by the Bank of England that lending is the primary channel through which money is created. Any loan automatically creates an off-setting deposit in a bank's balance sheet and through multiplier effect further deposits (McLeay et al., 2014). We thus define: $\Delta Y_{i t}=$ $\left(\Delta \text { Deposits }_{i t}, \Delta \text { Lending }_{i t}, \Delta G D P_{i t}, \pi_{i t}\right)^{\prime}$.

${ }^{26}$ To maximize power we sequentially drop insignificant trailing lags of the windfall shock. For conciseness, we do not report other equations in the SVAR system.
} 
when unit costs increase (not reported in the table to save space), and price-driven windfalls lead to only some repayment. When we look at the change in net foreign borrowing of banks using IMF data we find that only quantity shocks lead to more foreign borrowing by banks (not reported in the table to save space), a result that is significant only at the $10 \%$ level, but no significant impact of natural resource price shocks (column 17).

In summary, compared to similarly booming economies, windfall gains from natural resource price changes result in lower deposits and no significant changes in lending to the private sector. Windfall gains from natural resource price gains are thus not intermediated through the domestic financial system. There is some evidence that national liabilities are being paid down, but this seems to go through government books rather than affecting banks' net foreign borrowings.

Does country heterogeneity determine the response of lending? The results in Table 6 show important cross-country variation in the relationship between natural resource windfall gains and private sector lending. As our sample contains natural resource rich countries at very different levels of financial development, here we present regressions on the relationship between price changes in natural resources and private sector lending across countries with different degrees of financial liberalization. Specifically, we interact the price change in natural resources with seven different indicators of a country's legal system quality (Rule of Law), dummy variables for the existence of credit controls, directed credit, interest rate controls, state ownership, restrictions on capital account transactions, and an overall financial reform index, based on the previous five dummy variables (with all variables four periods lagged), with data from Abiad et al. (2008). While most of the coefficients on the concurrent and lagged changes in natural resource prices continue to enter insignificantly, some of the interactions enter significantly. Specifically, we find that lagged price changes have a positive effect in countries with higher levels of rule of law (column 1) and more liberalized financial system (as proxied by limited or no credit controls or directed credit, interest rate controls, government ownership or restrictions on capital account liberalization), as can be seen in columns (2) - (6). We also find that lagged price changes have a positive effect on private sector lending in countries with higher indices of financial reforms (column 7), an effect that holds even without controlling for deposits and GDP changes (column 8). These findings suggest that the insignificant relationships that we documented above between price changes and private sector lending is driven by financially repressed countries and countries with a poor contractual framework. This can also be interpreted as suggesting that many natural resource countries have limited 
absorption capacity in their financial systems due to financial repression and the lack of a conducive institutional framework.

Does the quality of lending deteriorate? The results in Table 7 show that natural resource related windfall gains result in higher non-performing loans in a country's banking system after two to three years. Here we regress the change in the share of non-performing loans in total loans (columns 1 and 2) and the log change in the total volume of non-performing loans (columns 3 and 4) and concurrent and lagged changes in price changes plus all the other variables we have included in previous regressions. We find a positive and significant change in the share of non-performing loans in total loans two years after a price increase in natural resources (columns 1 and 2) and a positive increase in the volume of non-performing loans two, three and four years after a price increase in natural resources. This can be interpreted as a decrease in the quality of lending decisions after a natural resource windfall gain.

\subsection{Bank-level evidence of the effect of natural resource windfalls}

We next turn to bank-level data to explore the robustness of our findings so far to the use of micro- rather than aggregate data. We have data available for almost 20,000 banks across 132 countries over the period 1986 to 2008. After conditioning on observables and dropping large clusters we are left with 1,601 banks in 105 countries between 1991 and $2008 .{ }^{27} \mathrm{We}$ include bank dummies, which also absorb country dummies. We modify the baseline model to include bank-level units of observation and regress:

$$
\Delta F_{i b t}=\beta_{1} \Delta P_{i t}+\beta_{2} \Delta Q_{i t}+\beta_{3} \Delta U C_{i t}+\gamma_{1} \Delta X_{i t}+\gamma_{2} \Delta Z_{i b t}+c_{b}+\varepsilon_{i b t}
$$

where $F$ is a bank-year level observation on the log of total deposits and short-term borrowing or log gross loans, $P$ is the natural resource price index, $Q$ the natural resource quantity index, $U C$ the natural resource unit cost index, $\mathrm{X}$ is an array of control variables at the country-year level including initial financial development, the rate of inflation and GDP growth, $\mathrm{Z}$ is an array of standard bank-year level characteristics including log total assets (size of the bank), net loans over total assets, and the non-interest share of total operating income, $i$ denotes country, $b$ bank, and $t$ year. We include bank $\left(c_{b}\right)$ fixed effects and cluster standard errors at

\footnotetext{
${ }^{27}$ We drop large countries with many banks (Germany and the United States) because simulations have shown that cluster-robust standard errors can be biased downwards if the clusters are unbalanced in size. Rogers (1994) suggests that no cluster should contain more than five per cent of the data.
} 
the country level. We also test for the differential effect of resource rent shocks on banks of different ownership. Specifically, we conjecture that foreign-owned banks might be less susceptible to the effects of natural resource rents, given their possible reliance on parent bank funding and lower susceptibility to government's moral suasion.

The results in Table 8 show that changes in resource prices significantly reduce the bank-level volume of deposits for countries that otherwise experience similar growth rates, supporting our earlier findings at the country level. The coefficients in the bank-level regressions are of similar size as the regressions on the country-level. Specifically, a $10 \%$ increase in natural resource prices results in a $1.3 \%$ reduction in deposits. These regressions control for bank-fixed effects and the global growth in deposits. When exploring differences across banks of different ownership (column 2), we find no significant difference between domestic and foreign-owned banks. ${ }^{28}$

The bank-level regressions also show a negative, though not significant impact of natural resource price shocks on private sector lending growth as the aggregate regressions in Table 5. As before, we find no differential effect across banks of different ownership.

Finally, the results in columns (5) and (6) show a significant positive relationship between resource price shocks and banks' investment into government securities. Specifically, a $10 \%$ positive shock to natural resource prices results in a $2.4 \%$ increase in banks' government holding (column 5), unless the bank is foreign-owned, in which case the effect is a negative one if one adds up contemporaneous and lagged effects.

In summary, the bank-level regressions confirm our aggregate regressions in that natural resource price shocks result in lower growth in financial system deposits and no significant impact on bank lending. At the same time, banks hold more government securities following a natural resource price shock. As in the case of the aggregate regressions, it is important to note that these results are effectively comparing a positive growth shock due to natural resource rents with a positive growth not due to natural resource rent changes. While there is some evidence for bank-level variation, such as foreign banks not increasing their government security holdings after a natural resource rent shock, overall this evidence points again to a process of dis-intermediation following exogenous natural resource rent increases, consistent with the overall story of a natural resource curse in the financial sector documented in the literature.

${ }^{28} \mathrm{We}$ also explored the level of institutions for differential effects among banks, but neither affected the results. 


\section{Robustness}

In this section, we subject our baseline regressions of changes in deposits and private sector lending to a series of additional robustness tests. First, we control for giant oil and gas field discoveries as additional exogenous source of variation in natural resource rents. Second, we gauge whether our findings are robust to dropping the largest natural resource producers for whom the assumption of being a price taker might not necessarily hold. Third, we consider the differential effects of windfall gains from natural resource rents across countries with and without sovereign wealth funds. Finally, we test the sensitivity of our findings to the use of different price indices.

\subsection{Controlling for giant oil and gas field discoveries}

The literature has recently started to use discoveries of giant oil and gas fields to identify the effects of natural resources. For example, Arezki et al. (2015) use a dataset from Horn (2003) on giant oil discoveries (i.e., at least 500 million ultimately recoverable barrels) to isolate the precise timing when expectations change and find that the investment ratio turns positive and the ratio of the current account to GDP turns negative for the first few years after a giant oil discovery while the current account becomes positive after five to seven years when production on average starts. Our focus is on the short run effects of an increase in natural resource revenue, rather than anticipation effects of discoveries which may happen long before the revenue starts flowing. Nevertheless, to see if such giant discoveries affect our results, we use the same data base and include lagged effects of discoveries in our baseline model. First, we use dummies equal to 1 in any year between 1960 and 2003 that a country discovers at least one oil or gas field with a size of at least 500 millions of barrels of oil equivalent (MMBOE) ultimately recoverable reserves, zero otherwise. ${ }^{29}$ Second, we measure discoveries as the log of field size in terms of ultimately recoverable reserves discovered.

The results in Table 9 show that these discoveries do not affect our main results, nor when we limit ourselves to shocks to producers of hydrocarbons (coal, oil and gas). We still find a relative decline in bank deposits following a resource price shock. Similarly, we find no significant impact of natural resource price shocks on private sector lending. The discoveries themselves tend to decrease deposits with a delay of 6 years and private sector lending with a

${ }^{29} \mathrm{~A}$ factor of $1 / .006$ is applied to convert gas in trillions of cubic feet to equivalent million barrels of oil. 
delay of 2 years, but the effects are small. ${ }^{30}$ However, reinterpreting discoveries of oil and gas field as an even more exogenous measure for increases in natural resource wealth confirms our finding of a crowding out of financial intermediation by banks following an increase in natural resource wealth.

\subsection{Price takers versus price makers and top quartile of resource producers}

So far we have assumed that world price shocks are exogenous and that by controlling for changes in quantities and costs we can identify exogenous natural resource windfalls due to world price changes. Some producers of natural resources produce a large share of world supply, however. These countries possess some unknown degree of price setting power. In Table 10 we exclude from the sample each metal or mineral's main producer. Specifically, we calculate for each country the average production of each commodity over time and drop the top producer for each commodity. ${ }^{31}$ The baseline results are robust to this exercise, with a negative and significant effect of natural resource price shocks on deposits and a negative but insignificant effect on private sector lending.

Conversely, when limiting the sample to the most resource dependent countries, we find even stronger effects, with the negative effect on private sector lending now turning significant. The larger the degree of natural resource dependence (the average share of total resource rents in GDP) of an economy, the more adversely affected is the financial sector.

\subsection{Sovereign wealth funds}

Natural resource rich countries have different regulatory frameworks, ownership structures and taxation systems to appropriate gains from natural resource exploitation. While a detailed analysis of these differences is beyond the scope of this paper, we focus on one specific element in this framework, sovereign wealth funds.

\footnotetext{
${ }^{30}$ In Arezki et al. (2015), the effect on the savings rate enters with $10 \%$ confidence in lags 8 and 9. Partly, this could reflect that we include all oil, gas and coal production and thus include many more and smaller fields, such that we combine the effect of new production from fields and declining production from existing fields. However, by measuring production of hydrocarbons directly, we also allow for new technology to increase production in existing fields, while Arezki et al. (2016) assume that fields decrease production over time by a power law since geological pressure declines over time. That is true of any well, but it is not necessarily true of a field, in which additional wells may be drilled to increase production (see also Anderson et al., 2017). In fact, we find nearly zero correlation between lags of discovery and changes in country level oil and gas production.

${ }^{31}$ Although we observe 15 metals and minerals we drop 9 countries because some countries are the largest producer in multiple commodities. We drop Australia, Canada, Chile, China, Germany, Mexico, Saudi Arabia, South Africa, and the United States. We also tried dropping all OPEC members, but this did not change the results.
} 
Countries with sovereign wealth funds might be better able to smooth external shocks by for example keeping resource revenues in offshore accounts rather than letting all of them flow into the domestic economy. Norway for example, invests oil revenue directly abroad and only consumes the annual return on investment. We attempt to control for this possibility by constructing an indicator equal to 1 for each country-year in which a country has a natural resource based sovereign wealth fund. This is admittedly a crude measure because there is wide variation in the size of funds, their political independence and their management. ${ }^{32} \mathrm{With}$ this caveat in mind, our regressions presented in Table 11 show significantly stronger negative effects in both the short and the long run (adding up all the coefficients of the lags) on both deposits and lending for countries with a sovereign wealth fund. However, this effect is due to major oil exporters having sovereign wealth funds, such as Saudi Arabia. Deposits, but not lending, actually grow for non-OPEC member countries with sovereign wealth funds $(-0.036$ $+0.086=+0.05)$, which fits the experience of Norway. The differences in the way in which SWFs are run thus matters for the degree of intermediation by the private sector of windfall resource revenue.

\subsection{Varying price index methodologies}

Lastly, we show the robustness of our findings to the use of different price indices. We have so far used the Paasche price index with base year 1970, but another commonly used index is the Laspeyres chained index, where we allow the base year to change over time. Specifically, we allow for the index to be chained to weights lagged one to three years. Table 11 shows that these choices do not affect the main result that deposits decline significantly with a natural resource price shocks while there is a negative but insignificant effect on private sector lending.

\section{Conclusion}

An extensive literature has shown that natural resources can exacerbate challenges of macroeconomic management. Another extensive literature has shown the importance of the financial system for economic development. While one of its primary functions is to

\footnotetext{
${ }^{32}$ See for example Bernstein et al. (2013). Countries with a natural resource based sovereign wealth fund are: Algeria, Azerbaijan, Botswana, Brunei Darussalam, Chile, Equatorial Guinea, Gabon, Iraq, Kazakhstan, Kiribati, Kuwait, Libya, Mauritania, Mexico, Norway, Oman, Qatar, Russian Federation, Saudi Arabia, Trinidad and Tobago, Turkmenistan, United Arab Emirates, United States, Venezuela.
} 
intermediate domestic savings into domestic investment, the financial system can also serve as important absorption tool for windfall gains, such as arising from natural resource rents.

Our results show that the financial system plays a limited if any role in absorbing windfall gains, especially in country with less conducive institutional frameworks and repressed financial systems. Specifically, controlling for the level of financial development, inflation, GDP growth and country fixed-effects, we find a relative decline in the volume of financial sector deposits in countries that experience an unexpected natural resource windfall. Compared to the counterfactual of a country growing at similar speed, a doubling of commodity price inflation induces a relative decline of deposit growth by $3.4 \%$, but increases relative growth of foreign assets by $9.6 \%$ and government deposits with central banks by $19.3 \%$, which in turn raises government consumption but not private lending. Moreover, we find that the relative volume of loans at the bank level also declines, although the decline in lending at the aggregate level is mostly due to the decrease in deposits.

The smaller role for the financial sector in intermediating the resource boom may be a reason why the quality of investment decisions decreases (as proxied by an increase in the share of non-performing loans) and may help to explain why natural resource rents tend be associated with slow aggregate growth in countries with less developed (financial) institutions. Our results thus stress the importance of financial system development for economic growth, including in resource-rich countries. Strengthening financial institutions and financial reform is essential to turn future windfall natural resource income into more productive investment. 


\section{References}

Abiad, A., E. Detragiache and T. Tressel.2008. A New Database of Financial Reforms, IMF Working Paper No. 08/266.

Acemoglu D, Robinson JA, Verdier T. 2004. Kleptocracy and divide-and-rule: a theory of personal rule. J. Eur. Econ. Assoc. 2:162-92

Afonso, António, Ludger Schuknecht, and Vito Tanzi, 2010. Public Sector Efficiency: Evidence for New EU Member States and Emerging Markets, Applied Economics, Vol. 42, No.17, pp. 2147-64.

Aghion, P., P. Bacchetta, R. Ranciere, and K. Rogoff, 2006, Exchange Rate Volatility and Productivity Growth: The Role of Financial Development, Journal of Monetary Economics 56, 494-513.

Andersen, Jorgen Juel, Niels Johannesen, David Dreyer Lassen and Elena Paltseva. 2017. Petro Rents, Political Institutions and Hidden Wealth: Evidence from Offshore Bank Accounts, Journal of the European Economic Association, forthcoming.

Anderson, S.T. \& Ryan Kellogg \& Stephen W. Salant, 2017. Hotelling Under Pressure, Journal of Political Economy, forthcoming.

Arcand, Jean Louis, Enrico Berkes, Ugo Panizza 2015. Too much finance? Journal of Economic Growth 20(2) 105-148.

Arellano, M. and S.R. Bond, 1991. Some specification tests for panel data: Monte Carlo evidence and an application to employment equations, Review of Economic Studies 58, 277-298.

Arezki, R., F. van der Ploeg and F. Toscani, 2016. Shifting Frontiers in Global Resource Wealth: The Role of Policies and Institutions, OxCarre Research Paper 180.

Arezki, R, Valerie A. Ramey amd Liugang Sheng, 2017. News Shocks in Open Economies: Evidence from Giant Oil Discoveries, Quarterly Journal of Economics, forthcoming.

Bates, R.H., 1981. Markets and States in Tropical Africa. University of California Press, Berkeley.

Bazzi, Samuel and Christopher Blattman. 2014. Economic Shocks and Conflict: Evidence from Commodity Prices, American Economic Journal: Macroeconomics, 6(4): 1-38.

Beck, Thorsten, 2011. Finance and Oil Is There a Natural Resource Curse in Financial Development? In: Rabah Arezki, Thorvaldur Gylfason and Amadou Sy (Eds.): Beyond the Curse: Policies to Harness the Power of Natural Resources, Washington DC: IMF, 81-106

Bernstein, S., J. Lerner, and A. Schoar. 2013. The Investment Strategies of Sovereign Wealth Funds, Journal of Economic Perspectives, Volume 27, Number 2, 219-238. 
Bhattacharyya, Sambit and Roland Hodler, 2014. Do Natural Resource Revenues Hinder Financial Development? The Role of Political Institutions, World Development 57 101113.

Blanchard, Olivier, Jonathan D. Ostry, Atish R. Ghosh, Marcos Chamon 2015. Are Capital Inflows Expansionary Or Contractionary? Theory, Policy Implications, And Some Evidence, NBER Working Paper 21619.

Bolt, Katharine, Mampite Matete and Michael Clemens, 2002. Manual for Calculating Adjusted Net Savings, Environment Department, World Bank, September.

Bond, S.R., 2002. Dynamic Panel Data Models: A Guide to Micro Data Methods and Practice, IFS WP CWP09/02.

Caballero, R. J., and A. Krishnamurthy, 2004, Fiscal Policy and Financial Depth, NBER Working Paper No. 10532 (Cambridge, Massachusetts: National Bureau of Economic Research).

Corden, W. Max and J. Peter Neary, 1982. Booming Sector and De-Industrialisation in a Small Open Economy, The Economic Journal 92, No. 368, 825-848.

Deaton, Angus \& Miller, Ron, 1996. International Commodity Prices, Macroeconomic Performance and Politics in Sub-Saharan Africa, Journal of African Economies, Centre for the Study of African Economies (CSAE) 5(3), 99-191.

Feenstra, Robert C., Robert Inklaar and Marcel P. Timmer 2015. The Next Generation of the Penn World Table" forthcoming American Economic Review, available for download at www.ggdc.net/pwt

T. Harding and A.J. Venables, 2016. The implications of natural resource exports for nonresource trade, IMF Economic Review 64(2), pages 268-302.

Horn, M.K. 2003. Giant Fields 1868-2003 (CD-ROM) in Halbouty, M.K., ed., Giant Oil and Gas Fields of the Decade, 1990-1999, Houston, AAPG Memoir 78.

Jacks, D.S., 2013. A Typology of Real Commodity Prices in the Long Run, NBER Working Paper No. 18874.

Lane, P. and G.M. Milesi-Ferretti, 2007. The External Wealth of Nations Mark II: Revised and Extended Estimates of Foreign Assets and Liability, 1970-2004. Journal of International Economics 73, 223-50.

Lütkepohl, H. 2006. New Introduction to Multiple Time Series Analysis. Springer Berlin Heidelberg. pp764

Mansoorian A. 1991. Resource discoveries and 'excessive' external borrowing. Economic Journal 101:1497-509

McLeay, M., A. Radia and R. Thomas. 2014. Money creation in the modern economy. Bank of England Quarterly Bulletin Q1, 1014. 
Manzano O, Rigobon R. 2007. Resource curse or debt overhang. In Natural Resources: Neither Curse nor Destiny, ed. D Lederman, WF Maloney, pp. 41-70. Washington, DC: World Bank

Mishra, P., Montiel, P. \& Spilimbergo, A. 2012, Monetary Transmission in Low-Income Countries: Effectiveness and Policy Implications IMF Economic Review 60, 270-302.

Nickell, Stephen J, 1981. Biases in Dynamic Models with Fixed Effects, Econometrica 49(6), 1417-26, November.

J. Peter Neary, 1988. Determinants of the Equilibrium Real Exchange Rate, The American Economic Review 78, 210-215.

Ploeg F. van der and S. Poelhekke. 2009a. Volatility and the natural resource curse. Oxford Economic Papers 61, 727-60

Ploeg, F. van der and S. Poelhekke, 2009b. The Volatility Curse: Revisiting the Paradox of Plenty, CESifo Working Paper 2616.

Ploeg F. van der and S. Poelhekke, 2010. The pungent smell of 'red herrings': Subsoil assets, rents, volatility and the resource curse Journal of Environmental Economics and Management 60(1) 44-55.

Ploeg, F. van der and A.J. Venables, 2012. Natural Resource Wealth: The Challenge of Managing a Windfall, Annual Review of Economics 4 315-337.

Ploeg, F. van der and A.J. Venables, 2013. Absorbing a windfall of foreign exchange: Dutch disease dynamics, Journal of Development Economics 103 229-243.

Robinson, James A., and Ragnar Torvik. 2005. White Elephants. Journal of Public Economics, 89(2-3):197-210.

Rogers, W. 1994. Regression standard errors in clustered samples, Stata Technical Bulletin, vol. 3 , issue 13 .

Svensson, Jakob. 2000. Foreign aid and rent-seeking. Journal of International Economics 51(2) 437-461.

Tornell A, Lane PR. 1999. The voracity effect. American Economic Review 89:22-46

Tsui, K., 2011. More Oil, Less Democracy: Evidence from Worldwide Crude Oil Discoveries, Economic Journal, Royal Economic Society 121(551), 89-115.

Pedro C. Vicente. 2010. Does oil corrupt? Evidence from a natural experiment in West Africa. Journal of Development Economics 92, 28-38.

World Bank. 2011. The Changing Wealth of Nations : Measuring Sustainable Development in the New Millennium. Environment and Development. World Bank. 


\begin{tabular}{|c|c|c|c|c|}
\hline \multicolumn{5}{|c|}{$\begin{array}{l}\text { Table } 1 \\
\text { Natural resource-rich countries have small financial sectors }\end{array}$} \\
\hline & \multicolumn{2}{|c|}{ Private credit/GDP } & \multirow{2}{*}{$\begin{array}{c}\begin{array}{c}\text { Bank } \\
\text { deposits } \\
\text { over GDP }\end{array} \\
{[3]}\end{array}$} & \multirow{2}{*}{$\begin{array}{c}\begin{array}{c}\text { Private credit } \\
\text { over bank } \\
\text { deposits }\end{array} \\
{[4]}\end{array}$} \\
\hline & {$[1]$} & {$[2]$} & & \\
\hline Total mineral rents over GDP (t-1) & $\begin{array}{c}-0.643 * * * \\
(0.111)\end{array}$ & $\begin{array}{c}-0.697 * * * \\
(0.159)\end{array}$ & $\begin{array}{c}-0.397 * * * \\
(0.091)\end{array}$ & $\begin{array}{c}-1.204 * * * \\
(0.396)\end{array}$ \\
\hline log GDP per capita (t-1) & $\begin{array}{c}0.314 * * * \\
(0.044)\end{array}$ & $\begin{array}{c}0.412^{* * *} \\
(0.061)\end{array}$ & $\begin{array}{c}0.223 * * * \\
(0.048)\end{array}$ & $\begin{array}{c}0.384 * * * \\
(0.081)\end{array}$ \\
\hline Institutions (t-1) & & $\begin{array}{c}0.001 \\
(0.002)\end{array}$ & & \\
\hline Country FE & Yes & Yes & Yes & Yes \\
\hline Year FE & Yes & Yes & Yes & Yes \\
\hline Observations & 4,446 & 2,465 & 4,454 & 4,439 \\
\hline Number of countries & 156 & 122 & 156 & 156 \\
\hline Years & $1971-2008$ & $1985-2008$ & $1971-2008$ & 1971-2008 \\
\hline R-squared & 0.367 & 0.259 & 0.387 & 0.093 \\
\hline
\end{tabular}

Notes: This table shows OLS regressions to estimate the correlation between countries' dependence on natural resource production (Total mineral rents over GDP) and the size of their financial sector. Total mineral rents over $G D P(t-1)$ is the value of mineral production net of extraction costs, where minerals include oil, gas, coal, bauxite, copper, lead, nickel, phosphate, tin, zinc, gold, silver and iron ore. The the size of their financial sector is measured as the volume of private credit over GDP in columns 1 and 2, and as the volume of bank deposits over GDP in column 3. Institutions are the sum of sum of corruption, rule of law, government stability, investment profile and bureacratic quality. Robust standard errors are clustered by country shown in parentheses. A constant, country and year fixed effects are included but not shown. ${ }^{* * *}, * *, *$ correspond to the $1 \%, 5 \%$, and $10 \%$ level of significance, respectively. 


\section{Table 2}

\section{The effect of natural resource windfalls on deposits without and with controlling for GDP growth}

\begin{tabular}{|c|c|c|c|c|c|c|c|c|}
\hline & & $\Delta \log$ gross & $\begin{array}{l}\Delta \log \text { household } \\
\text { final }\end{array}$ & $\begin{array}{c}\Delta \log \text { non- } \\
\text { household final }\end{array}$ & $\begin{array}{c}\Delta \text { log central } \\
\text { government }\end{array}$ & \multicolumn{3}{|c|}{$\Delta \log$ financial system deposits } \\
\hline & {$[1]$} & (2) & (3) & (4) & $(5)$ & $(6)$ & (7) & $(8)$ \\
\hline$\Delta \log$ mineral price index & $\begin{array}{c}0.125 * * * \\
(0.032)\end{array}$ & $\begin{array}{c}0.387^{* * *} \\
(0.049)\end{array}$ & $\begin{array}{c}0.097 * * * \\
(0.011)\end{array}$ & $\begin{array}{c}0.097 * * * \\
(0.018)\end{array}$ & $\begin{array}{c}0.100 * * * \\
(0.015)\end{array}$ & $\begin{array}{c}0.066^{* * *} \\
(0.013)\end{array}$ & $\begin{array}{c}0.023 \\
(0.016)\end{array}$ & $\begin{array}{c}-0.063 * * * \\
(0.012)\end{array}$ \\
\hline$\Delta \log$ mineral quantity index & $\begin{array}{l}0.040 * * * \\
(0.012)\end{array}$ & $\begin{array}{c}0.047 \\
(0.037)\end{array}$ & $\begin{array}{c}0.010 \\
(0.007)\end{array}$ & $\begin{array}{l}0.032 * * \\
(0.016)\end{array}$ & $\begin{array}{l}0.020 * * \\
(0.009)\end{array}$ & $\begin{array}{l}-0.008 \\
(0.007)\end{array}$ & $\begin{array}{c}-0.011 * * \\
(0.005)\end{array}$ & $\begin{array}{c}-0.021 * * * \\
(0.006)\end{array}$ \\
\hline$\Delta \log$ mineral unit cost index & $\begin{array}{c}0.003 \\
(0.045)\end{array}$ & $\begin{array}{c}0.065 \\
(0.052)\end{array}$ & $\begin{array}{c}0.193 * * * \\
(0.032)\end{array}$ & $\begin{array}{c}0.289 * * * \\
(0.067)\end{array}$ & $\begin{array}{c}0.193 * * * \\
(0.033)\end{array}$ & $\begin{array}{c}0.135 * * * \\
(0.034)\end{array}$ & $\begin{array}{c}0.035 \\
(0.025)\end{array}$ & $\begin{array}{c}0.028 \\
(0.026)\end{array}$ \\
\hline Lagged dependent variable & $\begin{array}{l}-0.053 \\
(0.043)\end{array}$ & $\begin{array}{c}-0.197 * * * \\
(0.036)\end{array}$ & $\begin{array}{c}0.066 * * \\
(0.026)\end{array}$ & $\begin{array}{l}-0.125 \\
(0.134)\end{array}$ & $\begin{array}{c}0.068 * * \\
(0.028)\end{array}$ & $\begin{array}{c}0.294 * * * \\
(0.034)\end{array}$ & $\begin{array}{c}0.216^{* * *} \\
(0.034)\end{array}$ & $\begin{array}{c}0.186 * * * \\
(0.033)\end{array}$ \\
\hline Rate of inflation & $\begin{array}{c}0.021 \\
(0.017)\end{array}$ & $\begin{array}{l}-0.026 \\
(0.032)\end{array}$ & $\begin{array}{c}-0.034 * * \\
(0.016)\end{array}$ & $\begin{array}{c}-0.131 * * * \\
(0.032)\end{array}$ & $\begin{array}{c}-0.096 * * * \\
(0.023)\end{array}$ & $\begin{array}{l}-0.070 \\
(0.051)\end{array}$ & $\begin{array}{c}-0.096 * * \\
(0.043)\end{array}$ & $\begin{array}{c}-0.150 * * * \\
(0.048)\end{array}$ \\
\hline log GDP per capita (t-1) & $\begin{array}{c}0.027 \\
(0.023)\end{array}$ & $\begin{array}{c}-0.077 * * * \\
(0.028)\end{array}$ & $\begin{array}{c}0.025 \\
(0.017)\end{array}$ & $\begin{array}{c}0.024 \\
(0.025)\end{array}$ & $\begin{array}{c}0.024 \\
(0.019)\end{array}$ & & & \\
\hline Financial development (t-1) & $\begin{array}{c}-0.001 * * * \\
(0.000)\end{array}$ & $\begin{array}{l}-0.000 * \\
(0.000)\end{array}$ & $\begin{array}{c}-0.001 * * * \\
(0.000)\end{array}$ & $\begin{array}{c}-0.001 * * * \\
(0.000)\end{array}$ & $\begin{array}{c}-0.001 * * * \\
(0.000)\end{array}$ & $\begin{array}{c}-0.001 * * * \\
(0.000)\end{array}$ & $\begin{array}{c}-0.000 * * * \\
(0.000)\end{array}$ & $\begin{array}{l}-0.000 * \\
(0.000)\end{array}$ \\
\hline$\Delta$ log real exchange rate & $\begin{array}{c}0.269 * * * \\
(0.041)\end{array}$ & & & & & & & \\
\hline$\Delta \log$ non-mineral GDP & & & & & & & $\begin{array}{c}0.571 * * * \\
(0.061)\end{array}$ & \\
\hline$\Delta \log$ GDP & & & & & & & & $\begin{array}{c}0.880 * * * \\
(0.031)\end{array}$ \\
\hline Country FE & Yes & Yes & Yes & Yes & Yes & Yes & Yes & Yes \\
\hline Observations & 3,323 & 3,265 & 3,446 & 3,064 & 3,495 & 2,975 & 2,975 & 2,975 \\
\hline Number of countries & 126 & 130 & 131 & 110 & 132 & 122 & 122 & 122 \\
\hline R-squared & 0.060 & 0.088 & 0.083 & 0.073 & 0.091 & 0.124 & 0.366 & 0.458 \\
\hline
\end{tabular}

Notes: This table shows OLS regressions to estimate the effect of unexpected and exogenous windfall in natural resource revenue based on world prices ( $\Delta$ log mineral price index) on aggregate savings, investment and consumption behavior. Columns 6 to 8 estimate the effect on total financial system deposits, sequentially controlling for the growth rate in non-mineral GDP and total GDP. By controlling for total GDP growth we estimate the differential effect of a windfall on countries that experience similar booms or busts but who experience them for different reasons. Robust standard errors are clustered by country shown in parentheses. A constant and country fixed effects are included but not shown. ${ }^{* * *},{ }^{* *},{ }^{*}$ correspond to the $1 \%, 5 \%$, and $10 \%$ level of significance, respectively. 


\section{Table 3, Panel A \\ Natural resource windfalls and the relative decline in private sector}

\begin{tabular}{|c|c|c|c|c|c|c|c|c|}
\hline Panel A: VAR & $\begin{array}{l}\Delta \text { log financial } \\
\text { system deposits }\end{array}$ & $\Delta \log$ GDP & Rate of inflation & $\begin{array}{c}\Delta \text { log bank } \\
\text { deposits }\end{array}$ & $\begin{array}{l}\Delta \text { log offshore } \\
\text { bank deposits }\end{array}$ & $\begin{array}{c}\Delta \text { log foreign } \\
\text { assets (banking } \\
\text { institutions) }\end{array}$ & $\begin{array}{c}\Delta \log \\
\text { government } \\
\text { deposits with } \\
\text { banks }\end{array}$ & $\begin{array}{c}\Delta \log \\
\text { government } \\
\text { deposits with } \\
\text { central bank }\end{array}$ \\
\hline & \multicolumn{3}{|c|}{$V A R$ reduced form } & $V A R$ & $V A R$ & $V A R$ & $V A R$ & $V A R$ \\
\hline & {$[1]$} & [2] & {$[3]$} & {$[4]$} & {$[5]$} & {$[6]$} & [7] & {$[8]$} \\
\hline$\Delta \log$ mineral price index & $\begin{array}{c}0.078 * * * \\
(0.017)\end{array}$ & $\begin{array}{c}0.148^{* * * *} \\
(0.019)\end{array}$ & $\begin{array}{c}0.066 * * * \\
(0.013)\end{array}$ & $\begin{array}{c}0.078 * * * \\
(0.016)\end{array}$ & $\begin{array}{l}-0.035 \\
(0.047)\end{array}$ & $\begin{array}{c}0.166^{* * *} \\
(0.045)\end{array}$ & $\begin{array}{c}0.137 * * * \\
(0.051)\end{array}$ & $\begin{array}{l}0.212 * * \\
(0.089)\end{array}$ \\
\hline$\Delta \log$ mineral price index $(\mathrm{t}-1)$ & $\begin{array}{c}0.067 * * * \\
(0.022)\end{array}$ & $\begin{array}{l}0.036^{*} \\
(0.019)\end{array}$ & $\begin{array}{l}-0.014 \\
(0.014)\end{array}$ & $\begin{array}{c}0.069 * * * \\
(0.018)\end{array}$ & $\begin{array}{c}0.006 \\
(0.059)\end{array}$ & $\begin{array}{l}-0.025 \\
(0.045)\end{array}$ & $\begin{array}{c}0.070 \\
(0.049)\end{array}$ & $\begin{array}{c}0.084 \\
(0.104)\end{array}$ \\
\hline$\Delta \log$ mineral price index $(\mathrm{t}-2)$ & $\begin{array}{l}0.043 * * \\
(0.020)\end{array}$ & $\begin{array}{c}0.023 \\
(0.016)\end{array}$ & $\begin{array}{l}-0.006 \\
(0.010)\end{array}$ & $\begin{array}{l}0.043 * * \\
(0.018)\end{array}$ & $\begin{array}{l}0.104^{*} \\
(0.057)\end{array}$ & $\begin{array}{c}0.006 \\
(0.030)\end{array}$ & $\begin{array}{l}-0.030 \\
(0.052)\end{array}$ & $\begin{array}{l}-0.006 \\
(0.090)\end{array}$ \\
\hline$\Delta \log$ mineral price index $(\mathrm{t}-3)$ & $\begin{array}{l}0.044 * * \\
(0.018)\end{array}$ & $\begin{array}{l}0.032 * * \\
(0.013)\end{array}$ & $\begin{array}{c}0.003 \\
(0.014)\end{array}$ & $\begin{array}{c}0.042 * * * \\
(0.015)\end{array}$ & $\begin{array}{c}0.277 * * * \\
(0.061)\end{array}$ & $\begin{array}{l}-0.005 \\
(0.060)\end{array}$ & $\begin{array}{c}0.063 \\
(0.044)\end{array}$ & $\begin{array}{l}-0.105 \\
(0.078)\end{array}$ \\
\hline$\Delta \log$ mineral price index $(\mathrm{t}-4)$ & $\begin{array}{c}0.014 \\
(0.017)\end{array}$ & $\begin{array}{c}0.006 \\
(0.014)\end{array}$ & $\begin{array}{l}-0.002 \\
(0.009)\end{array}$ & $\begin{array}{c}0.017 \\
(0.016)\end{array}$ & $\begin{array}{c}0.216^{* * *} \\
(0.050)\end{array}$ & $\begin{array}{c}0.019 \\
(0.049)\end{array}$ & $\begin{array}{l}0.115 * * \\
(0.049)\end{array}$ & $\begin{array}{l}-0.002 \\
(0.072)\end{array}$ \\
\hline Lagged dependent variable & $\begin{array}{c}0.354 * * * \\
(0.065)\end{array}$ & $\begin{array}{l}0.111 * * \\
(0.044)\end{array}$ & $\begin{array}{c}0.563 * * * \\
(0.043)\end{array}$ & $\begin{array}{c}0.359 * * * \\
(0.043)\end{array}$ & $\begin{array}{c}-0.354 * * * \\
(0.068)\end{array}$ & $\begin{array}{c}-0.204 * * * \\
(0.054)\end{array}$ & $\begin{array}{c}-0.186^{* * *} \\
(0.025)\end{array}$ & $\begin{array}{c}-0.184^{* * *} * \\
(0.062)\end{array}$ \\
\hline Rate of inflation (t-1) & $\begin{array}{c}0.067 * * \\
(0.030)\end{array}$ & $\begin{array}{c}0.033 \\
(0.029)\end{array}$ & & $\begin{array}{c}0.102 * * * \\
(0.024)\end{array}$ & $\begin{array}{c}0.153 \\
(0.097)\end{array}$ & $\begin{array}{c}-0.060 \\
(0.042)\end{array}$ & $\begin{array}{c}-0.143^{* *} \\
(0.059)\end{array}$ & $\begin{array}{c}-0.029 \\
(0.035)\end{array}$ \\
\hline$\Delta \log$ GDP (t-1) & $\begin{array}{c}-0.058 \\
(0.060)\end{array}$ & & $\begin{array}{c}-0.221 * * * \\
(0.043)\end{array}$ & $\begin{array}{c}-0.093 * \\
(0.053)\end{array}$ & $\begin{array}{c}0.098 \\
(0.076)\end{array}$ & $\begin{array}{c}0.306^{* *} \\
(0.119)\end{array}$ & $\begin{array}{c}0.373 * * * \\
(0.092)\end{array}$ & $\begin{array}{c}0.410 * * \\
(0.205)\end{array}$ \\
\hline$\Delta \log$ financial system deposits (t-1) & & $\begin{array}{c}0.056 * * \\
(0.025)\end{array}$ & $\begin{array}{c}0.030 \\
(0.033)\end{array}$ & & & & & \\
\hline Financial development $(\mathrm{t}-(\mathrm{s}+1))$ & $\begin{array}{c}-0.001 * * * \\
(0.000)\end{array}$ & $\begin{array}{c}-0.000^{* * *} \\
(0.000)\end{array}$ & $\begin{array}{l}-0.000 \\
(0.000)\end{array}$ & $\begin{array}{c}-0.001 * * * \\
(0.000)\end{array}$ & $\begin{array}{c}0.001 * * * \\
(0.000)\end{array}$ & $\begin{array}{l}-0.000 \\
(0.000)\end{array}$ & $\begin{array}{l}-0.000 \\
(0.001)\end{array}$ & $\begin{array}{l}-0.000 \\
(0.001)\end{array}$ \\
\hline $\begin{array}{l}\text { Controls for quantity and unit cost index, } \\
\text { lags } 0 \text {-s }\end{array}$ & & Yes & & Yes & Yes & Yes & Yes & Yes \\
\hline Country FE & & Yes & & Yes & Yes & Yes & Yes & Yes \\
\hline Observations & & 2,559 & & 2,561 & 1,083 & 2,538 & 2,365 & 2,507 \\
\hline Number of countries & & 115 & & 121 & 111 & 124 & 122 & 128 \\
\hline Years & & $1975-2008$ & & $1975-2008$ & $1997-2008$ & $1975-2008$ & $1975-2008$ & $1975-2008$ \\
\hline R-squared & 0.144 & 0.162 & 0.519 & 0.140 & 0.188 & 0.066 & 0.057 & 0.058 \\
\hline
\end{tabular}

Table continues on next page. 


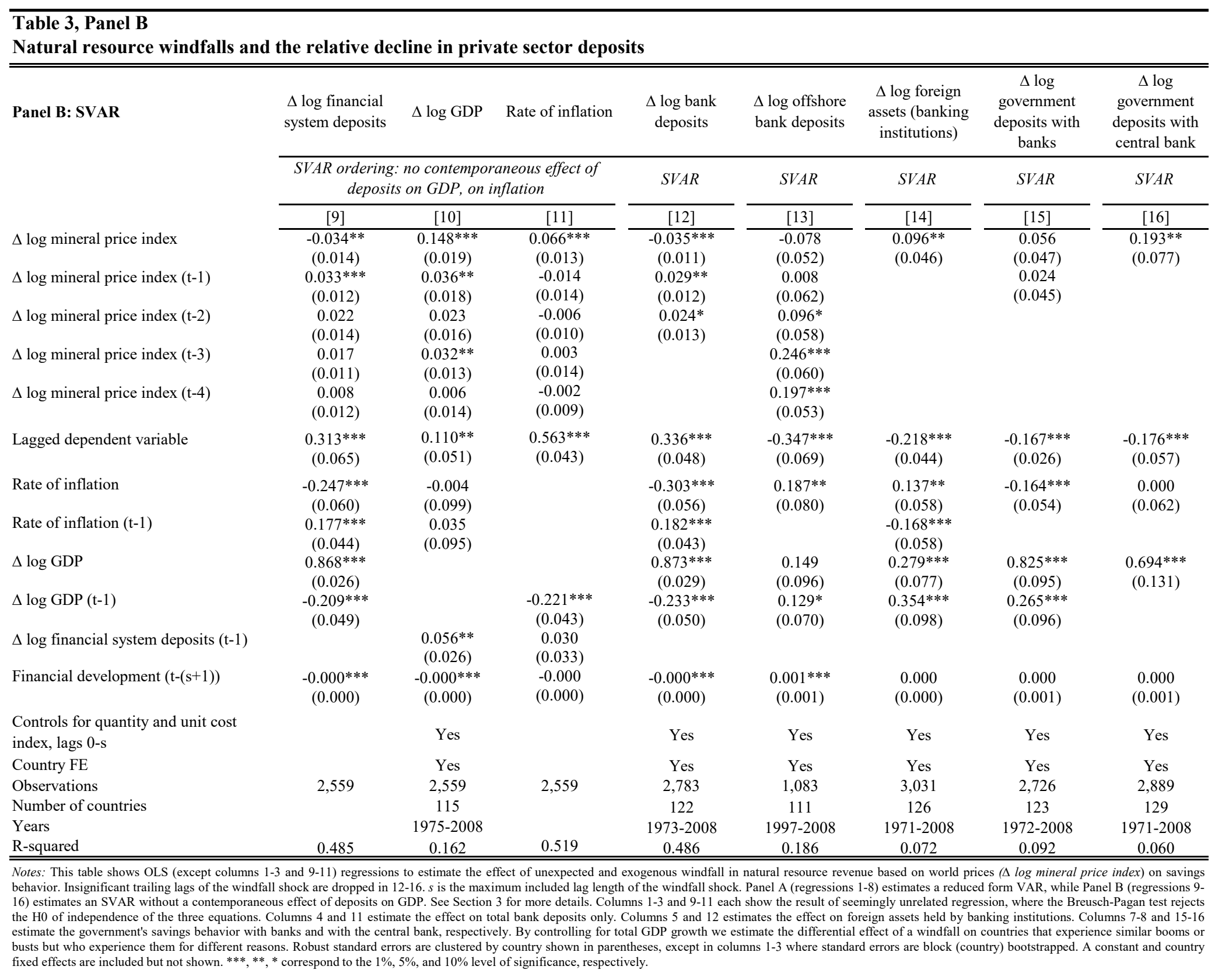


Table 4

Do government deposits lead to spending or to lending?

\begin{tabular}{|c|c|c|}
\hline & $\begin{array}{l}\Delta \text { log central } \\
\text { government } \\
\text { consumption } \\
\text { expenditure }\end{array}$ & $\begin{array}{c}\Delta \log \text { private } \\
\text { credit }\end{array}$ \\
\hline & {$[1]$} & {$[2]$} \\
\hline$\Delta$ log government deposits with central bank & $\begin{array}{c}0.016^{* * *} \\
(0.005)\end{array}$ & $\begin{array}{c}0.003 \\
(0.004)\end{array}$ \\
\hline$\Delta$ log government deposits with central bank (t-1) & $\begin{array}{c}0.017 * * * \\
(0.004)\end{array}$ & $\begin{array}{c}0.002 \\
(0.004)\end{array}$ \\
\hline$\Delta \log$ government deposits with central bank (t-2) & $\begin{array}{c}0.012 * * * \\
(0.004)\end{array}$ & $\begin{array}{c}0.001 \\
(0.002)\end{array}$ \\
\hline$\Delta \log$ government deposits with central bank (t-3) & $\begin{array}{c}0.004 \\
(0.003)\end{array}$ & \\
\hline$\Delta$ log government deposits with banks & $\begin{array}{c}0.051^{* * *} \\
(0.010)\end{array}$ & $\begin{array}{c}0.021^{* * * *} \\
(0.006)\end{array}$ \\
\hline$\Delta$ log government deposits with banks (t-1) & $\begin{array}{l}0.021 * * \\
(0.009)\end{array}$ & $\begin{array}{c}0.004 \\
(0.007)\end{array}$ \\
\hline$\Delta$ log government deposits with banks ( $\mathrm{t}-2)$ & $\begin{array}{l}0.013 * \\
(0.007)\end{array}$ & $\begin{array}{c}0.002 \\
(0.005)\end{array}$ \\
\hline$\Delta$ log government deposits with banks (t-3) & $\begin{array}{c}0.007 \\
(0.007)\end{array}$ & \\
\hline$\Delta \log$ foreign assets (banking institutions) & $\begin{array}{c}0.007 \\
(0.009)\end{array}$ & $\begin{array}{c}0.001 \\
(0.008)\end{array}$ \\
\hline$\Delta \log$ foreign assets (banking institutions) $(\mathrm{t}-1)$ & $\begin{array}{c}0.008 \\
(0.006)\end{array}$ & $\begin{array}{l}-0.001 \\
(0.007)\end{array}$ \\
\hline$\Delta \log$ foreign assets (banking institutions) $(\mathrm{t}-2)$ & $\begin{array}{c}0.007 \\
(0.008)\end{array}$ & $\begin{array}{c}0.004 \\
(0.007)\end{array}$ \\
\hline$\Delta \log$ foreign assets (banking institutions) $(\mathrm{t}-3)$ & $\begin{array}{c}0.001 \\
(0.006)\end{array}$ & \\
\hline$\Delta$ log private-sector deposits with banks & & $\begin{array}{c}0.196^{* * * *} \\
(0.038)\end{array}$ \\
\hline$\Delta$ log private-sector deposits with banks (t-1) & & $\begin{array}{c}0.087 * * * \\
(0.029)\end{array}$ \\
\hline$\Delta \log$ private-sector deposits with banks (t-2) & & $\begin{array}{l}0.042^{* *} \\
(0.019)\end{array}$ \\
\hline Lagged dependent variable & $\begin{array}{c}0.060 * * \\
(0.030)\end{array}$ & $\begin{array}{l}-0.023 \\
(0.026)\end{array}$ \\
\hline Rate of inflation & $\begin{array}{c}-0.119 * * * \\
(0.031)\end{array}$ & $\begin{array}{c}-0.429^{* * *} \\
(0.063)\end{array}$ \\
\hline Rate of inflation (t-1) & $\begin{array}{l}0.089^{* *} \\
(0.043)\end{array}$ & \\
\hline$\Delta \log$ GDP & & $\begin{array}{c}0.721 * * * \\
(0.045)\end{array}$ \\
\hline$\Delta \log$ GDP $(\mathrm{t}-1)$ & & $\begin{array}{c}0.166^{* * * *} \\
(0.045)\end{array}$ \\
\hline Financial development (t-s) & $\begin{array}{c}-0.001^{* * *} \\
(0.000)\end{array}$ & $\begin{array}{c}-0.002 * * * \\
(0.000)\end{array}$ \\
\hline Country FE & Yes & Yes \\
\hline Observations & 3,205 & 2,870 \\
\hline Number of countries & 150 & 140 \\
\hline Years & 1964-2008 & $1963-2008$ \\
\hline R-squared & 0.079 & 0.526 \\
\hline
\end{tabular}


Table 5, Panel A

\section{Natural resource windfalls and the relative decline in private credit}

\section{Panel A: Private credit}

$\Delta \log$ mineral price index

$\Delta \log$ mineral price index $(\mathrm{t}-1)$

$\Delta \log$ mineral price index $(\mathrm{t}-2)$

$\Delta \log$ mineral price index $(\mathrm{t}-3)$

$\Delta \log$ mineral price index $(\mathrm{t}-4)$

Lagged dependent variable

Rate of inflation

Rate of inflation (t-1)

$\Delta \log$ non-mineral GDP

$\Delta \log$ non-mineral GDP (t-1)

$\Delta \log$ GDP

$\Delta \log$ GDP (t-1)

$\Delta \log$ financial system deposits

$\Delta \log$ financial system deposits ( $\mathrm{t}-1)$

$\Delta \log$ private credit $(\mathrm{t}-1)$

Financial development (t- $(\mathrm{s}+1))$

Controls for quantity and unit cost index, lags 0 -s

Country FE

Observations

Number of countries

Years

R-squared

$\begin{array}{ccccccc}\Delta \log & \Delta \log & \Delta \log & \Delta \log & \Delta \log & \\ \text { private } & \text { private } & \text { private } & \text { private } & \text { financial } \\ \text { credit } & \text { credit } & \text { credit } & \text { credit } & \begin{array}{c}\text { system } \\ \text { deposits }\end{array} & \Delta \log \text { GDP } & \begin{array}{c}\text { Rate of } \\ \text { inflation }\end{array} \\ & & & & \end{array}$

SVAR ordering: no contemporaneous effect of lending, on deposits, on GDP, on inflation

\begin{tabular}{cccc}
\hline & {$[1]$} & & {$[2]$} \\
\cline { 1 - 1 } $0.110^{* * *}$ & & $0.070 * * *$ \\
$(0.018)$ & & $(0.018)$ \\
$0.080 * * *$ & & 0.026 \\
$(0.021)$ & & $(0.018)$ \\
$0.068 * * *$ & & $0.031 *$ \\
$(0.020)$ & & $(0.018)$ \\
$0.029 *$ & & -0.008 \\
$(0.017)$ & & $(0.019)$ \\
$0.055^{* * *}$ & & $0.025 * *$ \\
$(0.015)$ & & $(0.011)$ \\
0.068 & & -0.028 \\
$(0.047)$ & & $(0.043)$ \\
$-0.128 * * *$ & & $-0.236 * * *$ \\
$(0.035)$ & & $(0.056)$
\end{tabular}

$\frac{[3]}{0.036^{* *}}$

\begin{tabular}{cccc}
\hline$[4]$ & {$[5]$} & {$[6]$} & {$[7]$} \\
\hline-0.012 & $-0.037 * *$ & $0.147 * * *$ & $0.061 * * *$ \\
$(0.017)$ & $(0.015)$ & $(0.019)$ & $(0.013)$
\end{tabular}

(0.015)

0.000

$0.033 * * *$

$0.036 * *$

$-0.013$

(0.015)

0.018

(0.019)

(0.012)

(0.018)

(0.014)

(0.014)

$-0.014$

0.027

0.020

0.022

$-0.008$

(0.020)

(0.014)

(0.017)

(0.010)

(0.015)

0.016

$-0.016$

0.014

$0.032 * *$

$-0.001$

(0.013)

(0.011)

(0.013)

(0.014)

(0.012)

$0.028 * *$

0.010

0.006

0.000

(0.014)

(0.012)

(0.014)

(0.008)

$-0.032$

0.013

$0.256 * * *$

$0.111^{* *}$

$0.577 * * *$

(0.041)

$(0.039)$

(0.063)

(0.054)

$(0.044)$

$-0.279 * * *$

(0.055)

$-0.300 * * *$

$-0.265 * * *$

$-0.002$

(0.094)

(0.058)

(0.100)

$0.059 \quad 0.199 * * * \quad 0.035$

(0.094)

(0.042)

(0.098)

$0.440 * * *$ (0.098) $0.143 * * *$ (0.042)

$\begin{array}{cc}0.594 * * * & 0.390 * * * \\ (0.168) & (0.141) \\ 0.137 * * & 0.049 \\ (0.063) & (0.050)\end{array}$

$$
\begin{gathered}
0.760 * * * \\
(0.128) \\
0.078 \\
(0.084) \\
0.254 * \\
(0.144) \\
0.087 \\
(0.080)
\end{gathered}
$$

$0.868 * * *$

(0.026)

$0.078-0.259 * * *$

(0.084) (0.051)

$-0.297 * * *$

$\begin{array}{ccc} & 0.059 * * & -0.043 \\ & (0.029) & (0.030) \\ 0.101 * * * & -0.006 & 0.148 * * * \\ (0.024) & (0.019) & (0.021) \\ -0.000 * * * & -0.000 * * * & 0.000 \\ (0.000) & (0.000) & (0.000)\end{array}$

$-0.002 * *$
$(0.000)$

$-0.001 * * *$

$-0.001 * * *$

$-0.001 * * *$

(0.000)

(0.000)

$(0.000)$

\begin{tabular}{cccccc} 
Yes & Yes & Yes & Yes & \\
& & & Yes & \\
Yes & Yes & Yes & \multicolumn{2}{c}{2,541} & \\
3,025 & 2,544 & 2,544 & \multicolumn{2}{c}{121} \\
134 & 121 & 121 & \multicolumn{4}{c}{$1975-2008$} & \\
$975-2008$ & $1975-2008$ & $1975-2008$ & 0.589 & 0.161 & 0.529 \\
0.107 & 0.424 & 0.504 & 0.551 & 0.489 &
\end{tabular}

Table continues on next page. 
Table 5, Panel B

Natural resource windfalls and the relative decline in private credit

\begin{tabular}{|c|c|c|c|c|}
\hline \multirow[t]{3}{*}{$\begin{array}{l}\text { Panel B: different causal ordering - } \\
\text { credit creates deposits }\end{array}$} & $\begin{array}{l}\Delta \text { log financial } \\
\text { system deposits }\end{array}$ & $\begin{array}{l}\Delta \log \text { private } \\
\text { credit }\end{array}$ & $\Delta \log$ GDP & Rate of inflation \\
\hline & \multicolumn{4}{|c|}{$\begin{array}{c}\text { SVAR ordering: no contemporaneous effect of deposits on lending, } \\
\text { on GDP, on inflation }\end{array}$} \\
\hline & {$[8]$} & [9] & {$[10]$} & [11] \\
\hline$\Delta \log$ mineral price index & $\begin{array}{c}-0.033^{* *} \\
(0.014)\end{array}$ & $\begin{array}{l}-0.022 \\
(0.017)\end{array}$ & $\begin{array}{c}0.147^{* * *} \\
(0.019)\end{array}$ & $\begin{array}{c}0.061 * * * \\
(0.013)\end{array}$ \\
\hline$\Delta \log$ mineral price index $(t-1)$ & $\begin{array}{c}0.031 * * * \\
(0.012)\end{array}$ & $\begin{array}{l}0.008 \\
(0.019)\end{array}$ & $\begin{array}{c}0.036^{* *} \\
(0.018)\end{array}$ & $\begin{array}{l}-0.013 \\
(0.014)\end{array}$ \\
\hline$\Delta \log$ mineral price index $(\mathrm{t}-2)$ & $\begin{array}{c}0.013 \\
(0.015)\end{array}$ & $\begin{array}{l}0.032^{*} \\
(0.019)\end{array}$ & $\begin{array}{c}0.022 \\
(0.017)\end{array}$ & $\begin{array}{l}-0.008 \\
(0.010)\end{array}$ \\
\hline$\Delta \log$ mineral price index $(\mathrm{t}-3)$ & $\begin{array}{l}0.016 \\
(0.011)\end{array}$ & $\begin{array}{l}-0.012 \\
(0.013)\end{array}$ & $\begin{array}{l}0.032^{* *} \\
(0.013)\end{array}$ & $\begin{array}{l}-0.001 \\
(0.014)\end{array}$ \\
\hline$\Delta \log$ mineral price index $(\mathrm{t}-4)$ & $\begin{array}{c}0.004 \\
(0.011)\end{array}$ & $\begin{array}{l}0.031 * * \\
(0.015)\end{array}$ & $\begin{array}{c}0.006 \\
(0.014)\end{array}$ & $\begin{array}{c}0.000 \\
(0.008)\end{array}$ \\
\hline Lagged dependent variable & $\begin{array}{c}0.224^{* * *} \\
(0.065)\end{array}$ & $\begin{array}{c}0.038 \\
(0.035)\end{array}$ & $\begin{array}{c}0.111^{* *} \\
(0.054)\end{array}$ & $\begin{array}{c}0.577 * * * \\
(0.044)\end{array}$ \\
\hline Rate of inflation & $\begin{array}{c}-0.189 * * * \\
(0.055)\end{array}$ & $\begin{array}{c}-0.367 * * * \\
(0.081)\end{array}$ & $\begin{array}{l}-0.002 \\
(0.100)\end{array}$ & \\
\hline Rate of inflation (t-1) & $\begin{array}{c}0.177 * * * \\
(0.040)\end{array}$ & $\begin{array}{c}0.109 \\
(0.079)\end{array}$ & $\begin{array}{l}0.035 \\
(0.098)\end{array}$ & \\
\hline \multicolumn{5}{|l|}{$\Delta \log$ non-mineral GDP } \\
\hline$\Delta \log$ GDP & $\begin{array}{l}0.665^{* * *} \\
(0.060)\end{array}$ & $\begin{array}{c}0.981 * * * \\
(0.037)\end{array}$ & & \\
\hline$\Delta \log$ GDP $(\mathrm{t}-1)$ & $\begin{array}{c}-0.261 * * * \\
(0.050)\end{array}$ & $\begin{array}{c}0.012 \\
(0.066)\end{array}$ & & $\begin{array}{l}-0.297 * * * \\
(0.045)\end{array}$ \\
\hline$\Delta \log$ private credit & $\begin{array}{c}0.207 * * * \\
(0.045)\end{array}$ & & & \\
\hline$\Delta \log$ private credit $(\mathrm{t}-1)$ & $\begin{array}{c}0.094 * * * \\
(0.023)\end{array}$ & & $\begin{array}{l}-0.006 \\
(0.019)\end{array}$ & $\begin{array}{c}0.148 * * * \\
(0.021)\end{array}$ \\
\hline$\Delta \log$ financial system deposits ( $\mathrm{t}-1)$ & & $\begin{array}{c}0.152 * * * \\
(0.057)\end{array}$ & $\begin{array}{c}0.059 * * \\
(0.029)\end{array}$ & $\begin{array}{l}-0.043 \\
(0.030)\end{array}$ \\
\hline Financial development $(\mathrm{t}-(\mathrm{s}+1))$ & $\begin{array}{l}-0.000 \\
(0.000)\end{array}$ & $\begin{array}{c}-0.001^{* * *} \\
(0.000)\end{array}$ & $\begin{array}{c}-0.000^{* * *} \\
(0.000)\end{array}$ & $\begin{array}{c}0.000 \\
(0.000)\end{array}$ \\
\hline $\begin{array}{l}\text { Controls for quantity and unit cost } \\
\text { index, lags } 0 \text {-s }\end{array}$ & \multicolumn{4}{|c|}{ Yes } \\
\hline Country FE & \multicolumn{4}{|c|}{ Yes } \\
\hline Observations & \multicolumn{4}{|c|}{2,541} \\
\hline Number of countries & \multicolumn{4}{|c|}{115} \\
\hline Years & \multicolumn{4}{|c|}{$1975-2008$} \\
\hline R-squared & 0.515 & 0.526 & 0.161 & 0.529 \\
\hline
\end{tabular}

Table continues on next page. 


\section{Table 5, Panel C \\ Natural resource windfalls and the relative decline in private credit}

\begin{tabular}{|c|c|c|c|c|c|c|}
\hline \multirow[t]{3}{*}{ Panel C: Other measures of credit } & $\begin{array}{l}\Delta \text { log claims on } \\
\text { central } \\
\text { government }\end{array}$ & $\begin{array}{c}\Delta \text { log claims on } \\
\text { state and local } \\
\text { governments }\end{array}$ & $\begin{array}{l}\Delta \text { log claims on } \\
\text { public non- } \\
\text { financial corp. }\end{array}$ & $\begin{array}{c}\Delta \log \text { gross total } \\
\text { national } \\
\text { liabilities }\end{array}$ & $\begin{array}{c}\Delta \log \text { national } \\
\text { gross debt } \\
\text { liabilities }\end{array}$ & $\begin{array}{c}\Delta \text { net foreign } \\
\text { borrowing by } \\
\text { banks over GDP } \\
\text { ((liabilities- } \\
\text { assets)/GDP) }\end{array}$ \\
\hline & SVAR & $S V A R$ & $S V A R$ & $S V A R$ & $S V A R$ & SVAR \\
\hline & {$[12]$} & {$[13]$} & {$[14]$} & {$[15]$} & {$[16]$} & {$[17]$} \\
\hline$\Delta \log$ mineral price index & $\begin{array}{l}-0.044 \\
(0.067)\end{array}$ & $\begin{array}{l}-0.006 \\
(0.184)\end{array}$ & $\begin{array}{l}-0.036 \\
(0.085)\end{array}$ & $\begin{array}{c}-0.032^{*} \\
(0.018)\end{array}$ & $\begin{array}{c}-0.044 * * \\
(0.020)\end{array}$ & $\begin{array}{l}-0.001 \\
(0.003)\end{array}$ \\
\hline$\Delta \log$ mineral price index $(\mathrm{t}-1)$ & & & & $\begin{array}{c}0.002 \\
(0.020)\end{array}$ & $\begin{array}{l}-0.016 \\
(0.023)\end{array}$ & \\
\hline$\Delta \log$ mineral price index $(\mathrm{t}-2)$ & & & & $\begin{array}{c}0.043 * * \\
(0.017)\end{array}$ & $\begin{array}{l}0.047 * \\
(0.026)\end{array}$ & \\
\hline$\Delta \log$ mineral price index $(\mathrm{t}-3)$ & & & & $\begin{array}{c}0.054 * * \\
(0.021)\end{array}$ & $\begin{array}{c}0.077^{* * *} \\
(0.028)\end{array}$ & \\
\hline$\Delta \log$ mineral price index $(\mathrm{t}-4)$ & & & & $\begin{array}{c}0.017 \\
(0.013)\end{array}$ & $\begin{array}{c}0.025 \\
(0.017)\end{array}$ & \\
\hline Lagged dependent variable & $\begin{array}{c}-0.242 * * * \\
(0.092)\end{array}$ & $\begin{array}{c}-0.229 * * * \\
(0.074)\end{array}$ & $\begin{array}{l}-0.238 \\
(0.146)\end{array}$ & $\begin{array}{c}0.068 \\
(0.047)\end{array}$ & $\begin{array}{c}0.099 \\
(0.061)\end{array}$ & $\begin{array}{l}-0.226 \\
(0.184)\end{array}$ \\
\hline Rate of inflation & $\begin{array}{c}-0.278 * \\
(0.162)\end{array}$ & $\begin{array}{c}-0.351^{*} \\
(0.195)\end{array}$ & $\begin{array}{c}-0.588 * * \\
(0.266)\end{array}$ & $\begin{array}{l}-0.002 \\
(0.009)\end{array}$ & $\begin{array}{c}0.008 \\
(0.011)\end{array}$ & $\begin{array}{l}-0.001 \\
(0.007)\end{array}$ \\
\hline Rate of inflation (t-1) & & & & & & \\
\hline$\Delta \log$ GDP & $\begin{array}{c}0.190 \\
(0.269)\end{array}$ & $\begin{array}{c}1.257^{* * *} \\
(0.233)\end{array}$ & $\begin{array}{c}0.464 * * \\
(0.225)\end{array}$ & $\begin{array}{c}0.011 \\
(0.054)\end{array}$ & $\begin{array}{c}0.016 \\
(0.053)\end{array}$ & $\begin{array}{c}0.034 * * \\
(0.016)\end{array}$ \\
\hline$\Delta \log$ GDP $(t-1)$ & & & & & & $\begin{array}{c}0.030 * * \\
(0.014)\end{array}$ \\
\hline$\Delta$ log financial system deposits & $\begin{array}{c}0.446 * * \\
(0.195)\end{array}$ & $\begin{array}{c}-0.192 * \\
(0.101)\end{array}$ & $\begin{array}{c}0.220 \\
(0.173)\end{array}$ & $\begin{array}{l}0.062 * \\
(0.033)\end{array}$ & $\begin{array}{c}0.054 * \\
(0.031)\end{array}$ & $\begin{array}{l}-0.016 \\
(0.011)\end{array}$ \\
\hline$\Delta \log$ financial system deposits $(\mathrm{t}-1)$ & & $\begin{array}{c}1.142 * * * \\
(0.227)\end{array}$ & & & & \\
\hline$\Delta$ log real exchange rate & & & & $\begin{array}{c}0.208 * * * \\
(0.049)\end{array}$ & $\begin{array}{c}0.163 * * * \\
(0.053)\end{array}$ & \\
\hline Financial development $(\mathrm{t}-(\mathrm{s}+1))$ & $\begin{array}{l}-0.001 \\
(0.000)\end{array}$ & $\begin{array}{c}-0.002 \\
(0.002)\end{array}$ & $\begin{array}{c}0.003 \\
(0.002)\end{array}$ & $\begin{array}{c}-0.001 * * * \\
(0.000)\end{array}$ & $\begin{array}{c}-0.001 * * * \\
(0.000)\end{array}$ & $\begin{array}{c}-0.000 * * \\
(0.000)\end{array}$ \\
\hline $\begin{array}{l}\text { Controls for quantity and unit cost } \\
\text { index, lags } 0-\mathrm{s}\end{array}$ & Yes & Yes & Yes & Yes & Yes & Yes \\
\hline Country FE & Yes & Yes & Yes & Yes & Yes & Yes \\
\hline Observations & 2,576 & 828 & 1,145 & 2,470 & 2,470 & 2,546 \\
\hline Number of countries & 116 & 51 & 68 & 114 & 114 & 113 \\
\hline Years & $1971-2008$ & $1971-2008$ & $1971-2008$ & $1975-2008$ & $1975-2008$ & $1971-2008$ \\
\hline R-squared & 0.094 & 0.102 & 0.097 & 0.096 & 0.083 & 0.061 \\
\hline
\end{tabular}

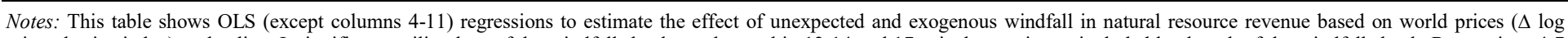

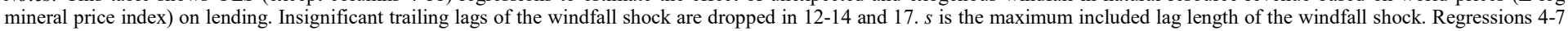

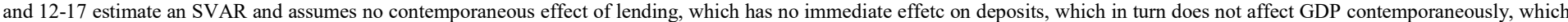

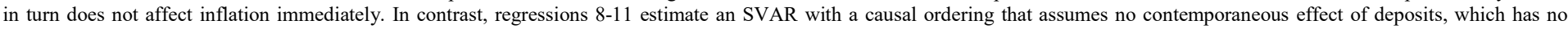

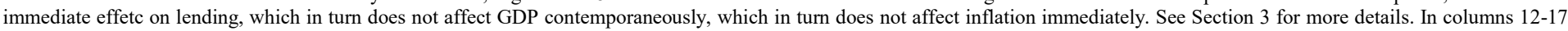

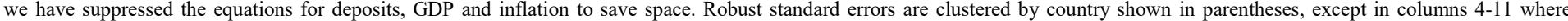

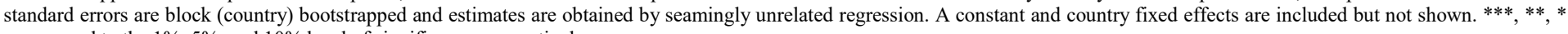
correspond to the $1 \%, 5 \%$, and $10 \%$ level of significance, respectively. 
Table 6

\section{Relative decline of credit in financially restrictive countries}

\begin{tabular}{|c|c|c|c|c|c|c|c|c|c|}
\hline & \multirow[b]{3}{*}{ interaction variable: } & \multicolumn{8}{|c|}{$\Delta \log$ private credit } \\
\hline & & \multirow{2}{*}{$\begin{array}{c}\text { rule of law } \\
\mathrm{e}[0,6]\end{array}$} & \multicolumn{5}{|c|}{ Degree of liberalization of $\mathrm{e}[0,3]$ : } & \multicolumn{2}{|c|}{ financial reform index $\mathrm{e}[0,1]$} \\
\hline & & & credit controls & directed credit & $\begin{array}{l}\text { interest rate } \\
\text { controls }\end{array}$ & $\begin{array}{c}\text { ownership of } \\
\text { banks } \\
\text { (privatization) }\end{array}$ & $\begin{array}{c}\text { capital account } \\
\text { transactions }\end{array}$ & & \\
\hline & & {$[1]$} & $(2)$ & (3) & (4) & (5) & $(6)$ & $(7)$ & $(8)$ \\
\hline$\Delta \log$ mineral price index & & $\begin{array}{l}-0.087 \\
(0.074)\end{array}$ & $\begin{array}{l}-0.011 \\
(0.036)\end{array}$ & $\begin{array}{c}0.003 \\
(0.035)\end{array}$ & $\begin{array}{l}-0.024 \\
(0.032)\end{array}$ & $\begin{array}{c}-0.015 \\
(0.031)\end{array}$ & $\begin{array}{l}-0.057 \\
(0.036)\end{array}$ & $\begin{array}{c}-0.054 \\
(0.045)\end{array}$ & $\begin{array}{c}0.021 \\
(0.045)\end{array}$ \\
\hline$\Delta \log$ mineral price index $(\mathrm{t}-1)$ & & $\begin{array}{l}-0.073 \\
(0.058)\end{array}$ & $\begin{array}{c}-0.089 * * \\
(0.039)\end{array}$ & $\begin{array}{l}-0.072^{*} \\
(0.038)\end{array}$ & $\begin{array}{l}-0.052 \\
(0.034)\end{array}$ & $\begin{array}{l}-0.045 \\
(0.033)\end{array}$ & $\begin{array}{c}-0.095 * * * \\
(0.035)\end{array}$ & $\begin{array}{c}-0.116^{* * *} \\
(0.041)\end{array}$ & $\begin{array}{l}-0.036 \\
(0.054)\end{array}$ \\
\hline$\Delta \log$ mineral price index $(\mathrm{t}-2)$ & & $\begin{array}{c}0.072 \\
(0.070)\end{array}$ & $\begin{array}{c}-0.069^{*} \\
(0.038)\end{array}$ & $\begin{array}{c}-0.054 \\
(0.036)\end{array}$ & $\begin{array}{c}-0.086^{* *} \\
(0.036)\end{array}$ & $\begin{array}{l}-0.036 \\
(0.031)\end{array}$ & $\begin{array}{c}-0.088^{* *} \\
(0.041)\end{array}$ & $\begin{array}{c}-0.111 * * * \\
(0.042)\end{array}$ & $\begin{array}{l}-0.082 \\
(0.056)\end{array}$ \\
\hline$\Delta \log$ mineral price index $(\mathrm{t}-3)$ & & $\begin{array}{c}-0.133^{* *} \\
(0.061)\end{array}$ & $\begin{array}{c}-0.107^{* *} \\
(0.041)\end{array}$ & $\begin{array}{c}-0.099 * * \\
(0.040)\end{array}$ & $\begin{array}{c}-0.102 * * * \\
(0.034)\end{array}$ & $\begin{array}{c}-0.063^{* *} \\
(0.025)\end{array}$ & $\begin{array}{c}-0.068^{* *} \\
(0.029)\end{array}$ & $\begin{array}{c}-0.116^{* * *} \\
(0.038)\end{array}$ & $\begin{array}{c}-0.084 * * \\
(0.040)\end{array}$ \\
\hline Direct effect of interaction variable & & $\begin{array}{l}-0.006 \\
(0.006)\end{array}$ & $\begin{array}{l}0.010^{*} \\
(0.005)\end{array}$ & $\begin{array}{l}0.009^{*} \\
(0.005)\end{array}$ & $\begin{array}{c}0.014 * * * \\
(0.005)\end{array}$ & $\begin{array}{c}0.004 \\
(0.006)\end{array}$ & $\begin{array}{l}0.011^{* *} \\
(0.005)\end{array}$ & $\begin{array}{c}0.064 * * * \\
(0.023)\end{array}$ & $\begin{array}{c}0.050 \\
(0.037)\end{array}$ \\
\hline$\Delta \log$ mineral price index & * Interaction variable (t-4) & $\begin{array}{c}0.019 \\
(0.019)\end{array}$ & $\begin{array}{l}-0.003 \\
(0.016)\end{array}$ & $\begin{array}{l}-0.011 \\
(0.015)\end{array}$ & $\begin{array}{c}0.005 \\
(0.014)\end{array}$ & $\begin{array}{c}0.007 \\
(0.018)\end{array}$ & $\begin{array}{c}0.027 \\
(0.019)\end{array}$ & $\begin{array}{c}0.060 \\
(0.080)\end{array}$ & $\begin{array}{c}0.103 \\
(0.080)\end{array}$ \\
\hline$\Delta \log$ mineral price index $(\mathrm{t}-1)$ & * Interaction variable (t-4) & $\begin{array}{c}0.029 * * \\
(0.014)\end{array}$ & $\begin{array}{c}0.058^{* * *} \\
(0.019)\end{array}$ & $\begin{array}{c}0.049 * * * \\
(0.018)\end{array}$ & $\begin{array}{l}0.032 * \\
(0.016)\end{array}$ & $\begin{array}{l}0.035^{*} \\
(0.018)\end{array}$ & $\begin{array}{c}0.056^{* * * *} \\
(0.016)\end{array}$ & $\begin{array}{c}0.230 * * * \\
(0.067)\end{array}$ & $\begin{array}{c}0.271 * * * \\
(0.089)\end{array}$ \\
\hline$\Delta \log$ mineral price index $(\mathrm{t}-2)$ & * Interaction variable (t-4) & $\begin{array}{l}-0.007 \\
(0.016)\end{array}$ & $\begin{array}{c}0.026 \\
(0.018)\end{array}$ & $\begin{array}{c}0.020 \\
(0.017)\end{array}$ & $\begin{array}{l}0.036^{* *} \\
(0.015)\end{array}$ & $\begin{array}{c}0.021 \\
(0.015)\end{array}$ & $\begin{array}{c}0.045^{* *} \\
(0.019)\end{array}$ & $\begin{array}{c}0.161 * * * \\
(0.061)\end{array}$ & $\begin{array}{c}0.195^{* *} \\
(0.081)\end{array}$ \\
\hline$\Delta \log$ mineral price index $(\mathrm{t}-3)$ & * Interaction variable (t-4) & $\begin{array}{c}0.037 * * * \\
(0.014)\end{array}$ & $\begin{array}{c}0.052 * * \\
(0.020)\end{array}$ & $\begin{array}{c}0.047 * * \\
(0.020)\end{array}$ & $\begin{array}{c}0.049 * * * \\
(0.015)\end{array}$ & $\begin{array}{c}0.027 * * \\
(0.013)\end{array}$ & $\begin{array}{l}0.022^{*} \\
(0.012)\end{array}$ & $\begin{array}{c}0.187 * * * \\
(0.057)\end{array}$ & $\begin{array}{c}0.248 * * * \\
(0.061)\end{array}$ \\
\hline Lagged dependent variable & & $\begin{array}{c}0.004 \\
(0.049)\end{array}$ & $\begin{array}{l}-0.036 \\
(0.056)\end{array}$ & $\begin{array}{l}-0.035 \\
(0.056)\end{array}$ & $\begin{array}{l}-0.046 \\
(0.055)\end{array}$ & $\begin{array}{l}-0.033 \\
(0.056)\end{array}$ & $\begin{array}{l}-0.048 \\
(0.055)\end{array}$ & $\begin{array}{l}-0.051 \\
(0.055)\end{array}$ & $\begin{array}{c}0.068 \\
(0.069)\end{array}$ \\
\hline Rate of inflation & & $\begin{array}{c}-0.169^{* *} \\
(0.073)\end{array}$ & $\begin{array}{l}-0.084 \\
(0.051)\end{array}$ & $\begin{array}{l}-0.085 \\
(0.052)\end{array}$ & $\begin{array}{l}-0.078 \\
(0.051)\end{array}$ & $\begin{array}{c}-0.093 * \\
(0.051)\end{array}$ & $\begin{array}{l}-0.085^{*} \\
(0.051)\end{array}$ & $\begin{array}{l}-0.077 \\
(0.051)\end{array}$ & $\begin{array}{c}-0.089^{* *} \\
(0.040)\end{array}$ \\
\hline$\Delta \log$ GDP & & $\begin{array}{c}0.728^{* * *} \\
(0.154)\end{array}$ & $\begin{array}{c}0.596 * * * \\
(0.107)\end{array}$ & $\begin{array}{c}0.597 * * * \\
(0.107)\end{array}$ & $\begin{array}{c}0.606^{* * *} \\
(0.110)\end{array}$ & $\begin{array}{c}0.608^{* * *} \\
(0.110)\end{array}$ & $\begin{array}{c}0.606^{* * *} \\
(0.108)\end{array}$ & $\begin{array}{c}0.600^{* * *} \\
(0.108)\end{array}$ & \\
\hline$\Delta \log$ GDP $(\mathrm{t}-1)$ & & $\begin{array}{c}0.233 * * * \\
(0.079)\end{array}$ & $\begin{array}{c}0.267 * * * \\
(0.086)\end{array}$ & $\begin{array}{c}0.266 * * * \\
(0.085)\end{array}$ & $\begin{array}{c}0.274 * * * \\
(0.085)\end{array}$ & $\begin{array}{c}0.258 * * * \\
(0.085)\end{array}$ & $\begin{array}{c}0.276^{* * *} \\
(0.085)\end{array}$ & $\begin{array}{c}0.277 * * * \\
(0.085)\end{array}$ & \\
\hline$\Delta$ log financial system deposits & & $\begin{array}{l}0.281^{*} \\
(0.143)\end{array}$ & $\begin{array}{c}0.428 * * * \\
(0.100)\end{array}$ & $\begin{array}{c}0.429 * * * \\
(0.100)\end{array}$ & $\begin{array}{c}0.421 * * * \\
(0.103)\end{array}$ & $\begin{array}{c}0.420^{* * *} \\
(0.103)\end{array}$ & $\begin{array}{c}0.425^{* * *} \\
(0.101)\end{array}$ & $\begin{array}{c}0.421 * * * \\
(0.101)\end{array}$ & \\
\hline Financial development (t-4) & & $\begin{array}{c}-0.002^{* * *} \\
(0.000)\end{array}$ & $\begin{array}{c}-0.001^{* * *} \\
(0.000)\end{array}$ & $\begin{array}{c}-0.001^{* * * *} \\
(0.000)\end{array}$ & $\begin{array}{c}-0.001^{* * * *} \\
(0.000)\end{array}$ & $\begin{array}{c}-0.001^{* * * *} \\
(0.000)\end{array}$ & $\begin{array}{c}-0.001^{* * * *} \\
(0.000)\end{array}$ & $\begin{array}{c}-0.002 * * * \\
(0.000)\end{array}$ & $\begin{array}{c}-0.002^{* * * *} \\
(0.000)\end{array}$ \\
\hline $\begin{array}{l}\text { Controls for quantity and unit cost } \\
\text { index, lags } 0 \text {-s }\end{array}$ & & Yes & Yes & Yes & Yes & Yes & Yes & Yes & Yes \\
\hline Country FE & & Yes & Yes & Yes & Yes & Yes & Yes & Yes & Yes \\
\hline Observations & & 1,593 & 1,783 & 1,783 & 1,783 & 1,783 & 1,783 & 1,783 & 1,783 \\
\hline Number of countries & & 104 & 76 & 76 & 76 & 76 & 76 & 76 & 76 \\
\hline R-squared & & 0.490 & 0.526 & 0.525 & 0.527 & 0.520 & 0.526 & 0.529 & 0.529 \\
\hline
\end{tabular}


Table 7

Windfalls and changes in the share on non-performing loans

\begin{tabular}{|c|c|c|c|c|}
\hline & \multicolumn{2}{|c|}{$\begin{array}{l}\Delta \text { Bank nonperfoming loans } \\
\text { to total gross loans }(\%)\end{array}$} & \multicolumn{2}{|c|}{$\begin{array}{c}\Delta \log \text { Bank nonperfoming } \\
\text { loans }\end{array}$} \\
\hline & {$[1]$} & {$[2]$} & [3] & {$[4]$} \\
\hline \multirow[t]{2}{*}{$\Delta \log$ mineral price index } & 0.697 & 0.329 & -0.110 & -0.126 \\
\hline & $(1.312)$ & $(1.236)$ & $(0.117)$ & $(0.110)$ \\
\hline \multirow[t]{2}{*}{$\Delta \log$ mineral price index $(\mathrm{t}-1)$} & $2.157^{*}$ & 1.605 & 0.186 & 0.189 \\
\hline & $(1.218)$ & $(1.187)$ & $(0.118)$ & $(0.120)$ \\
\hline \multirow[t]{2}{*}{$\Delta \log$ mineral price index $(\mathrm{t}-2)$} & $2.971 * *$ & $2.581 *$ & $0.301 * *$ & $0.338 * * *$ \\
\hline & $(1.487)$ & $(1.447)$ & $(0.121)$ & $(0.125)$ \\
\hline \multirow[t]{2}{*}{$\Delta \log$ mineral price index $(\mathrm{t}-3)$} & 1.918 & 1.440 & $0.247 * *$ & $0.318 * * *$ \\
\hline & $(1.189)$ & $(1.140)$ & $(0.103)$ & $(0.099)$ \\
\hline \multirow[t]{2}{*}{$\Delta \log$ mineral price index $(\mathrm{t}-4)$} & $2.451 * *$ & 1.260 & $0.210 * *$ & $0.232 * *$ \\
\hline & $(0.995)$ & $(0.937)$ & $(0.101)$ & $(0.097)$ \\
\hline \multirow[t]{2}{*}{ Lagged dependent variable } & -0.111 & -0.111 & -0.070 & -0.070 \\
\hline & $(0.107)$ & $(0.107)$ & $(0.066)$ & $(0.066)$ \\
\hline \multirow[t]{2}{*}{ Rate of inflation } & & & -0.346 & -0.421 \\
\hline & & & $(0.393)$ & $(0.328)$ \\
\hline \multirow[t]{2}{*}{$\Delta \log$ GDP } & -2.752 & & -0.102 & \\
\hline & $(2.486)$ & & $(0.389)$ & \\
\hline \multirow[t]{2}{*}{$\Delta \log$ GDP (t-1) } & $-6.648 *$ & & $-0.594 *$ & \\
\hline & $(3.655)$ & & $(0.350)$ & \\
\hline \multirow[t]{2}{*}{$\Delta \log$ GDP (t-2) } & & & -0.109 & \\
\hline & & & $(0.243)$ & \\
\hline \multirow[t]{2}{*}{$\Delta \log$ private credit } & -2.211 & & 0.316 & \\
\hline & $(1.620)$ & & $(0.243)$ & \\
\hline \multirow[t]{2}{*}{$\Delta \log$ private credit $(\mathrm{t}-1)$} & $3.947 * *$ & & 0.185 & \\
\hline & $(1.725)$ & & $(0.171)$ & \\
\hline \multirow[t]{2}{*}{$\Delta \log$ private credit (t-2) } & & & $0.195^{*}$ & \\
\hline & & & $(0.101)$ & \\
\hline \multirow[t]{2}{*}{ Financial development (t-5) } & $-0.030^{*}$ & $-0.030 *$ & -0.002 & $-0.004 * *$ \\
\hline & $(0.015)$ & $(0.017)$ & $(0.002)$ & $(0.002)$ \\
\hline $\begin{array}{l}\text { Controls for quantity and unit } \\
\text { cost index, lags } 0-4\end{array}$ & Yes & Yes & Yes & Yes \\
\hline Country FE & Yes & Yes & Yes & Yes \\
\hline Country FE & Yes & Yes & Yes & Yes \\
\hline Observations & 504 & 510 & 496 & 499 \\
\hline Number of countries & 83 & 83 & 82 & 82 \\
\hline Years & 2001-2007 & $2001-2007$ & $2001-2007$ & 2001-2007 \\
\hline R-squared & 0.134 & 0.047 & 0.132 & 0.097 \\
\hline
\end{tabular}

Notes: This table shows OLS regressions to estimate the effect of lags of unexpected and exogenous windfall in natural resource revenue based on world prices ( $\Delta$ log mineral price index) on the change in the share of nonperforming loans. Robust standard errors are clustered by country and shown in parentheses. A constant and fixed effects are included but not shown. $* * *, * *, *$ correspond to the $1 \%, 5 \%$, and $10 \%$ level of significance, respectively. 


\section{Table 8}

\section{Bank-level analysis: Natural resource windfalls and the relative}

\begin{tabular}{|c|c|c|c|c|c|c|c|}
\hline & & \multicolumn{2}{|c|}{$\begin{array}{l}\Delta \text { log total deposits and } \\
\text { short-term borrowing }\end{array}$} & \multicolumn{2}{|c|}{$\Delta \log$ gross loans } & \multicolumn{2}{|c|}{$\Delta \log$ government securities } \\
\hline & & {$[1]$} & {$[2]$} & [3] & [4] & {$[5]$} & {$[6]$} \\
\hline \multicolumn{2}{|l|}{$\Delta \log$ mineral price index } & $\begin{array}{c}-0.131 * * * \\
(0.042)\end{array}$ & $\begin{array}{c}-0.097 * * \\
(0.048)\end{array}$ & $\begin{array}{l}-0.035 \\
(0.026)\end{array}$ & $\begin{array}{l}-0.033 \\
(0.033)\end{array}$ & $\begin{array}{l}0.321^{* *} \\
(0.130)\end{array}$ & $\begin{array}{l}0.460 * * * \\
(0.133)\end{array}$ \\
\hline \multicolumn{2}{|l|}{$\Delta \log$ mineral price index $(\mathrm{t}-1)$} & $\begin{array}{c}0.074 \\
(0.057)\end{array}$ & $\begin{array}{c}0.071 \\
(0.071)\end{array}$ & $\begin{array}{l}0.075^{* *} \\
(0.034)\end{array}$ & $\begin{array}{l}0.112^{* *} \\
(0.046)\end{array}$ & $\begin{array}{c}0.013 \\
(0.125)\end{array}$ & $\begin{array}{c}0.187 \\
(0.163)\end{array}$ \\
\hline \multicolumn{2}{|l|}{$\Delta \log$ mineral price index $(\mathrm{t}-2)$} & $\begin{array}{l}-0.025 \\
(0.058)\end{array}$ & $\begin{array}{c}0.032 \\
(0.055)\end{array}$ & $\begin{array}{c}0.044 \\
(0.031)\end{array}$ & $\begin{array}{c}0.044 \\
(0.031)\end{array}$ & $\begin{array}{c}0.123 \\
(0.180)\end{array}$ & $\begin{array}{c}0.182 \\
(0.155)\end{array}$ \\
\hline \multicolumn{2}{|l|}{$\Delta \log$ mineral price index $(\mathrm{t}-3)$} & $\begin{array}{c}0.046 \\
(0.049)\end{array}$ & $\begin{array}{c}0.034 \\
(0.060)\end{array}$ & $\begin{array}{l}0.069^{* *} \\
(0.031)\end{array}$ & $\begin{array}{c}0.034 \\
(0.037)\end{array}$ & $\begin{array}{c}0.175 \\
(0.150)\end{array}$ & $\begin{array}{l}0.259^{*} \\
(0.145)\end{array}$ \\
\hline \multicolumn{2}{|l|}{ Lagged dependent variable } & $\begin{array}{c}-0.129 * * * \\
(0.023)\end{array}$ & $\begin{array}{c}-0.142 * * * \\
(0.031)\end{array}$ & $\begin{array}{c}-0.140^{* * *} \\
(0.048)\end{array}$ & $\begin{array}{c}-0.151^{* * *} \\
(0.050)\end{array}$ & $\begin{array}{c}-0.225^{* * *} \\
(0.023)\end{array}$ & $\begin{array}{l}-0.225^{* * *} \\
(0.022)\end{array}$ \\
\hline \multicolumn{2}{|l|}{ Rate of inflation } & $\begin{array}{c}0.000 \\
(0.088)\end{array}$ & $\begin{array}{l}-0.169 \\
(0.126)\end{array}$ & $\begin{array}{l}-0.038 \\
(0.034)\end{array}$ & $\begin{array}{c}-0.154 * * \\
(0.063)\end{array}$ & $\begin{array}{c}0.624 * * * \\
(0.133)\end{array}$ & $\begin{array}{c}1.008^{* * *} \\
(0.390)\end{array}$ \\
\hline \multicolumn{2}{|l|}{$\Delta \log$ GDP } & $\begin{array}{c}0.917 * * * \\
(0.163)\end{array}$ & $\begin{array}{c}0.987 * * * \\
(0.140)\end{array}$ & $\begin{array}{c}0.595 * * * \\
(0.081)\end{array}$ & $\begin{array}{c}0.620 * * * \\
(0.085)\end{array}$ & $\begin{array}{c}-1.120^{* * *} \\
(0.254)\end{array}$ & $\begin{array}{c}-1.033 * * * \\
(0.207)\end{array}$ \\
\hline \multicolumn{2}{|l|}{$\Delta \log$ GDP $(\mathrm{t}-1)$} & & & $\begin{array}{c}0.156 * * * \\
(0.056)\end{array}$ & $\begin{array}{c}0.143 * * \\
(0.068)\end{array}$ & $\begin{array}{c}-0.363^{* *} \\
(0.143)\end{array}$ & $\begin{array}{c}-0.367 * * \\
(0.150)\end{array}$ \\
\hline \multicolumn{2}{|l|}{$\Delta \log$ deposit } & & & $\begin{array}{c}0.398 * * * \\
(0.028)\end{array}$ & $\begin{array}{c}0.390^{* * * *} \\
(0.034)\end{array}$ & $\begin{array}{c}0.428^{* * * *} \\
(0.106)\end{array}$ & $\begin{array}{c}0.430^{* * * *} \\
(0.103)\end{array}$ \\
\hline \multicolumn{2}{|l|}{$\Delta \log$ deposit (t-1) } & & & $\begin{array}{l}0.094^{* *} \\
(0.042)\end{array}$ & $\begin{array}{c}0.124 * * * \\
(0.034)\end{array}$ & $\begin{array}{l}0.106^{* *} \\
(0.051)\end{array}$ & $\begin{array}{l}0.140^{* *} \\
(0.058)\end{array}$ \\
\hline \multicolumn{2}{|l|}{ Financial development (t-4) } & $\begin{array}{c}0.001 \\
(0.000)\end{array}$ & $\begin{array}{c}0.001 \\
(0.001)\end{array}$ & $\begin{array}{c}0.000 \\
(0.000)\end{array}$ & $\begin{array}{l}-0.000 \\
(0.000)\end{array}$ & $\begin{array}{l}-0.000 \\
(0.001)\end{array}$ & $\begin{array}{l}-0.000 \\
(0.001)\end{array}$ \\
\hline \multicolumn{2}{|l|}{ Bank's log tot assets (t-4) } & $\begin{array}{c}-0.031^{* *} \\
(0.015)\end{array}$ & $\begin{array}{c}-0.059 * * * \\
(0.016)\end{array}$ & $\begin{array}{c}-0.027 * * \\
(0.013)\end{array}$ & $\begin{array}{l}-0.027 \\
(0.019)\end{array}$ & $\begin{array}{c}0.001 \\
(0.027)\end{array}$ & $\begin{array}{l}-0.021 \\
(0.033)\end{array}$ \\
\hline \multicolumn{2}{|c|}{ Bank's Net Loans / Tot Assets (t-4) } & $\begin{array}{c}0.000 \\
(0.001)\end{array}$ & $\begin{array}{c}0.001 \\
(0.000)\end{array}$ & $\begin{array}{c}-0.002 * * * \\
(0.001)\end{array}$ & $\begin{array}{c}-0.002 * * * \\
(0.000)\end{array}$ & $\begin{array}{l}0.003^{*} \\
(0.002)\end{array}$ & $\begin{array}{c}0.002 \\
(0.002)\end{array}$ \\
\hline \multicolumn{2}{|l|}{$\begin{array}{l}\text { Bank's Non-interest share of } \\
\text { total operating income (t-4) }\end{array}$} & $\begin{array}{c}-0.000^{*} \\
(0.000)\end{array}$ & $\begin{array}{l}-0.000 \\
(0.000)\end{array}$ & $\begin{array}{c}0.000 \\
(0.000)\end{array}$ & $\begin{array}{l}-0.000 \\
(0.000)\end{array}$ & $\begin{array}{l}0.002 \\
(0.002)\end{array}$ & $\begin{array}{l}0.003 \\
(0.002)\end{array}$ \\
\hline \multicolumn{2}{|l|}{$\Delta$ log global deposit } & $\begin{array}{c}0.322 * * * \\
(0.073)\end{array}$ & $\begin{array}{c}0.574 * * * \\
(0.134)\end{array}$ & & & & \\
\hline$\Delta \log$ mineral price index & $*$ Bank foreign owned (t-4) & & $\begin{array}{l}-0.025 \\
(0.091)\end{array}$ & & $\begin{array}{c}0.050 \\
(0.053)\end{array}$ & & $\begin{array}{l}-0.486^{*} \\
(0.269)\end{array}$ \\
\hline$\Delta \log$ mineral price index $(\mathrm{t}-1)$ & $*$ Bank foreign owned (t-4) & & $\begin{array}{l}0.140 \\
(0.106)\end{array}$ & & $\begin{array}{l}-0.080 \\
(0.069)\end{array}$ & & $\begin{array}{c}-0.610^{* *} \\
(0.243)\end{array}$ \\
\hline$\Delta \log$ mineral price index $(\mathrm{t}-2)$ & * Bank foreign owned (t-4) & & $\begin{array}{l}-0.060 \\
(0.082)\end{array}$ & & $\begin{array}{l}0.076 \\
(0.086)\end{array}$ & & $\begin{array}{l}0.325 \\
(0.351)\end{array}$ \\
\hline$\Delta \log$ mineral price index $(\mathrm{t}-3)$ & * Bank foreign owned (t-4) & & $\begin{array}{l}0.020 \\
(0.083)\end{array}$ & & $\begin{array}{l}0.140^{*} \\
(0.082)\end{array}$ & & $\begin{array}{l}-0.255 \\
(0.200)\end{array}$ \\
\hline Bank foreign owned (t-4) & & & $\begin{array}{c}-0.033 * * \\
(0.017)\end{array}$ & & $\begin{array}{c}-0.036^{* * *} \\
(0.013)\end{array}$ & & $\begin{array}{l}0.130^{* *} \\
(0.064)\end{array}$ \\
\hline $\begin{array}{l}\text { Controls for quantity and unit } \\
\text { cost index, lags } 0 \text {-s }\end{array}$ & & Yes & Yes & Yes & Yes & Yes & Yes \\
\hline $\begin{array}{l}\text { Bank FE } \\
\text { Observations }\end{array}$ & & $\begin{array}{c}\text { Yes } \\
9,906\end{array}$ & $\begin{array}{c}\text { Yes } \\
7,217\end{array}$ & $\begin{array}{c}\text { Yes } \\
9,864\end{array}$ & $\begin{array}{c}\text { Yes } \\
7,184\end{array}$ & $\begin{array}{c}\text { Yes } \\
5,283\end{array}$ & $\begin{array}{c}\text { Yes } \\
3,951\end{array}$ \\
\hline
\end{tabular}


Table 9

Robustness: Controlling for giant oil and gas field discoveries

\begin{tabular}{|c|c|c|c|c|}
\hline \multirow[b]{2}{*}{ Discovery $=$} & \multicolumn{2}{|c|}{$\Delta$ log financial system deposits } & \multicolumn{2}{|c|}{$\Delta \log$ private credit } \\
\hline & \multicolumn{2}{|c|}{$\begin{array}{l}\text { Giant oil and gas field discovery } \\
\text { dummy }\end{array}$} & \multicolumn{2}{|c|}{$\begin{array}{l}\text { log giant oil and gas field ultimately } \\
\text { recoverable reserves discovered }\end{array}$} \\
\hline \multirow[t]{2}{*}{ Resource $=$} & all minerals & $\begin{array}{l}\text { hydrocarbons } \\
\text { only }\end{array}$ & all minerals & $\begin{array}{l}\text { hydrocarbons } \\
\text { only }\end{array}$ \\
\hline & {$[1]$} & {$[2]$} & {$[3]$} & {$[4]$} \\
\hline$\Delta \log$ resource price index & $\begin{array}{c}-0.034 * * * \\
(0.011)\end{array}$ & $\begin{array}{c}-0.033^{* * *} \\
(0.011)\end{array}$ & $\begin{array}{l}-0.012 \\
(0.016)\end{array}$ & $\begin{array}{l}-0.013 \\
(0.016)\end{array}$ \\
\hline$\Delta \log$ resource price index $(\mathrm{t}-1)$ & $\begin{array}{l}0.032 * * * \\
(0.012)\end{array}$ & $\begin{array}{l}0.032 * * * \\
(0.012)\end{array}$ & $\begin{array}{l}-0.006 \\
(0.015)\end{array}$ & $\begin{array}{l}-0.006 \\
(0.015)\end{array}$ \\
\hline$\Delta \log$ resource price index $(\mathrm{t}-2)$ & $\begin{array}{l}0.027 * * \\
(0.013)\end{array}$ & $\begin{array}{l}0.026 * * \\
(0.013)\end{array}$ & $\begin{array}{l}0.039 * * * \\
(0.014)\end{array}$ & $\begin{array}{c}0.038 * * * \\
(0.014)\end{array}$ \\
\hline$\Delta \log$ resource price index $(\mathrm{t}-3)$ & & & $\begin{array}{l}-0.014 \\
(0.015)\end{array}$ & $\begin{array}{l}-0.014 \\
(0.015)\end{array}$ \\
\hline$\Delta \log$ resource price index $(\mathrm{t}-4)$ & & & $\begin{array}{l}0.027 * * \\
(0.011)\end{array}$ & $\begin{array}{l}0.027 * * \\
(0.011)\end{array}$ \\
\hline Lagged dependent variable & $\begin{array}{l}0.335^{* * * *} \\
(0.049)\end{array}$ & $\begin{array}{l}0.335 * * * \\
(0.049)\end{array}$ & $\begin{array}{l}-0.007 \\
(0.044)\end{array}$ & $\begin{array}{l}-0.008 \\
(0.044)\end{array}$ \\
\hline Rate of inflation & $\begin{array}{c}-0.298 * * * \\
(0.056)\end{array}$ & $\begin{array}{l}-0.297 * * * \\
(0.056)\end{array}$ & $\begin{array}{c}-0.126 * * \\
(0.055)\end{array}$ & $\begin{array}{c}-0.126^{* *} \\
(0.055)\end{array}$ \\
\hline Rate of inflation (t-1) & $\begin{array}{c}0.181 * * * \\
(0.043)\end{array}$ & $\begin{array}{c}0.180 * * * \\
(0.043)\end{array}$ & & \\
\hline$\Delta \log$ GDP & $\begin{array}{c}0.871^{* * *} * \\
(0.028)\end{array}$ & $\begin{array}{c}0.871 * * * \\
(0.028)\end{array}$ & $\begin{array}{c}0.695 * * * \\
(0.114)\end{array}$ & $\begin{array}{c}0.695 * * * \\
(0.114)\end{array}$ \\
\hline$\Delta \log$ GDP $(\mathrm{t}-1)$ & $\begin{array}{c}-0.229 * * * \\
(0.050)\end{array}$ & $\begin{array}{c}-0.229^{* * *} \\
(0.050)\end{array}$ & $\begin{array}{c}0.208 * * * \\
(0.059)\end{array}$ & $\begin{array}{c}0.208 * * * \\
(0.059)\end{array}$ \\
\hline$\Delta \log$ financial system deposits & & & $\begin{array}{c}0.291 * * \\
(0.119)\end{array}$ & $\begin{array}{c}0.291 * * \\
(0.120)\end{array}$ \\
\hline Financial development $(\mathrm{t}-(\mathrm{s}+1))$ & $\begin{array}{c}-0.000 * * * \\
(0.000)\end{array}$ & $\begin{array}{c}-0.000^{* * *} * \\
(0.000)\end{array}$ & $\begin{array}{c}-0.001 * * * \\
(0.000)\end{array}$ & $\begin{array}{c}-0.001 * * * \\
(0.000)\end{array}$ \\
\hline Discovery & $\begin{array}{c}0.009 \\
(0.010)\end{array}$ & $\begin{array}{c}0.002 \\
(0.001)\end{array}$ & $\begin{array}{l}0.042 * \\
(0.022)\end{array}$ & $\begin{array}{l}0.006^{*} \\
(0.003)\end{array}$ \\
\hline Discovery (t-1) & $\begin{array}{l}-0.021 * \\
(0.011)\end{array}$ & $\begin{array}{l}-0.003^{*} \\
(0.002)\end{array}$ & $\begin{array}{l}-0.024 * \\
(0.012)\end{array}$ & $\begin{array}{l}-0.003 * \\
(0.002)\end{array}$ \\
\hline Discovery (t-2) & $\begin{array}{c}0.003 \\
(0.010)\end{array}$ & $\begin{array}{c}0.001 \\
(0.001)\end{array}$ & $\begin{array}{c}-0.029 * * \\
(0.013)\end{array}$ & $\begin{array}{c}-0.004^{* *} \\
(0.002)\end{array}$ \\
\hline Discovery (t-3) & $\begin{array}{c}0.011 \\
(0.009)\end{array}$ & $\begin{array}{c}0.001 \\
(0.001)\end{array}$ & $\begin{array}{c}-0.024 * \\
(0.012)\end{array}$ & $\begin{array}{l}-0.003 * \\
(0.002)\end{array}$ \\
\hline Discovery (t-4) & $\begin{array}{c}0.014 \\
(0.011)\end{array}$ & $\begin{array}{c}0.002 \\
(0.002)\end{array}$ & $\begin{array}{c}0.009 \\
(0.015)\end{array}$ & $\begin{array}{c}0.001 \\
(0.002)\end{array}$ \\
\hline Discovery (t-5) & $\begin{array}{l}-0.015 * \\
(0.008)\end{array}$ & $\begin{array}{c}-0.002 * \\
(0.001)\end{array}$ & $\begin{array}{c}-0.023 \\
(0.018)\end{array}$ & $\begin{array}{c}-0.003 \\
(0.003)\end{array}$ \\
\hline Discovery (t-6) & $\begin{array}{c}-0.028 * * \\
(0.011)\end{array}$ & $\begin{array}{c}-0.004^{* *} \\
(0.002)\end{array}$ & $\begin{array}{l}-0.019 * \\
(0.011)\end{array}$ & $\begin{array}{l}-0.002 \\
(0.002)\end{array}$ \\
\hline Discovery (t-7) & $\begin{array}{c}0.008 \\
(0.011)\end{array}$ & $\begin{array}{c}0.001 \\
(0.002)\end{array}$ & $\begin{array}{l}-0.005 \\
(0.015)\end{array}$ & $\begin{array}{l}-0.001 \\
(0.002)\end{array}$ \\
\hline Discovery $(\mathrm{t}-8)$ & $\begin{array}{c}0.010 \\
(0.010)\end{array}$ & $\begin{array}{c}0.001 \\
(0.001)\end{array}$ & $\begin{array}{c}0.002 \\
(0.012)\end{array}$ & $\begin{array}{c}0.000 \\
(0.002)\end{array}$ \\
\hline Discovery (t-9) & $\begin{array}{l}-0.009 \\
(0.009)\end{array}$ & $\begin{array}{l}-0.001 \\
(0.001)\end{array}$ & $\begin{array}{l}0.024 * \\
(0.013)\end{array}$ & $\begin{array}{l}0.003^{*} \\
(0.002)\end{array}$ \\
\hline Discovery (t-10) & $\begin{array}{l}-0.005 \\
(0.008)\end{array}$ & $\begin{array}{c}-0.001 \\
(0.001)\end{array}$ & $\begin{array}{l}-0.017 \\
(0.012)\end{array}$ & $\begin{array}{c}-0.002 \\
(0.002)\end{array}$ \\
\hline $\begin{array}{l}\text { Controls for quantity and unit cost } \\
\text { index, lags } 0 \text {-s }\end{array}$ & Yes & Yes & Yes & Yes \\
\hline $\begin{array}{l}\text { Country FE } \\
\text { Observations }\end{array}$ & $\begin{array}{c}\text { Yes } \\
2,784\end{array}$ & $\begin{array}{c}\text { Yes } \\
2,784\end{array}$ & $\begin{array}{c}\text { Yes } \\
2,579\end{array}$ & $\begin{array}{c}\text { Yes } \\
2,579\end{array}$ \\
\hline Number of countries & 122 & 122 & 121 & 121 \\
\hline R-squared & 0.486 & 0.486 & 0.504 & 0.504 \\
\hline
\end{tabular}

Notes: This table shows OLS regressions to estimate the effect of unexpected and exogenous windfall in natural resource revenue based on world prices $(\Delta \log$ mineral price index) on measures of deposit and credit growth, controlling for two measures of oil and gas field discovery. Insignificant trailing lags of the windfall shock are dropped. $s$ is the maximum included lag length of the windfall shock. Hydrocarbons include oil, natural gas and coal. Robust standard errors are clustered by country shown in parentheses. A constant and country fixed effects are included but not shown. ***,**,* correspond to the $1 \%, 5 \%$, and $10 \%$ level of significance, respectively. 
Table 10

Robustness: Selected samples

\begin{tabular}{|c|c|c|c|c|}
\hline & \multicolumn{2}{|c|}{$\Delta \log$ financial system deposits } & \multicolumn{2}{|c|}{$\Delta \log$ private credit } \\
\hline & $\begin{array}{c}\text { Price takers: } \\
\text { Excluding each } \\
\text { mineral's largest } \\
\text { producer }\end{array}$ & $\begin{array}{c}\text { Including only top } \\
\text { quartile of countries } \\
\text { by natural resource } \\
\text { dependence }\end{array}$ & $\begin{array}{c}\text { Price takers: } \\
\text { Excluding each } \\
\text { mineral's largest } \\
\text { producer }\end{array}$ & $\begin{array}{c}\text { Including only top } \\
\text { quartile of countries } \\
\text { by natural resource } \\
\text { dependence }\end{array}$ \\
\hline & {$[1]$} & {$[2]$} & {$[3]$} & {$[4]$} \\
\hline$\Delta \log$ mineral price index & $\begin{array}{c}-0.034 * * * \\
(0.011)\end{array}$ & $\begin{array}{c}-0.043^{* *} \\
(0.016)\end{array}$ & $\begin{array}{l}-0.010 \\
(0.017)\end{array}$ & $\begin{array}{c}-0.080 * * * \\
(0.024)\end{array}$ \\
\hline$\Delta \log$ mineral price index $(\mathrm{t}-1)$ & $\begin{array}{c}0.029 * * \\
(0.012)\end{array}$ & $\begin{array}{c}0.028 \\
(0.021)\end{array}$ & $\begin{array}{l}-0.001 \\
(0.015)\end{array}$ & $\begin{array}{l}-0.018 \\
(0.025)\end{array}$ \\
\hline$\Delta \log$ mineral price index $(\mathrm{t}-2)$ & $\begin{array}{l}0.024 * \\
(0.014)\end{array}$ & $\begin{array}{c}0.041 * * * \\
(0.014)\end{array}$ & $\begin{array}{c}0.034 * * \\
(0.014)\end{array}$ & $\begin{array}{c}0.045 * * \\
(0.021)\end{array}$ \\
\hline$\Delta \log$ mineral price index $(\mathrm{t}-3)$ & & $\begin{array}{c}0.039 * * \\
(0.015)\end{array}$ & $\begin{array}{l}-0.012 \\
(0.014)\end{array}$ & \\
\hline$\Delta \log$ mineral price index $(\mathrm{t}-4)$ & & & $\begin{array}{c}0.027 * * \\
(0.011)\end{array}$ & \\
\hline Lagged dependent variable & $\begin{array}{c}0.331 * * * \\
(0.052)\end{array}$ & $\begin{array}{c}0.246 * * * \\
(0.034)\end{array}$ & $\begin{array}{l}-0.009 \\
(0.044)\end{array}$ & $\begin{array}{l}-0.017 \\
(0.041)\end{array}$ \\
\hline Rate of inflation & $\begin{array}{c}-0.289^{* * *} \\
(0.056)\end{array}$ & $\begin{array}{c}-0.484 * * * \\
(0.053)\end{array}$ & $\begin{array}{c}-0.140 * * \\
(0.060)\end{array}$ & $\begin{array}{l}-0.088 \\
(0.056)\end{array}$ \\
\hline Rate of inflation (t-1) & $\begin{array}{c}0.170 * * * \\
(0.044)\end{array}$ & $\begin{array}{c}0.267 * * * \\
(0.042)\end{array}$ & & \\
\hline$\Delta \log$ GDP & $\begin{array}{c}0.882 * * * \\
(0.026)\end{array}$ & $\begin{array}{c}0.880 * * * \\
(0.042)\end{array}$ & $\begin{array}{c}0.699 * * * \\
(0.111)\end{array}$ & $\begin{array}{c}0.569 * * * \\
(0.107)\end{array}$ \\
\hline$\Delta \log$ GDP $(\mathrm{t}-1)$ & $\begin{array}{c}-0.234^{* * * *} \\
(0.055)\end{array}$ & $\begin{array}{c}-0.141^{* * * *} \\
(0.039)\end{array}$ & $\begin{array}{c}0.238 * * * \\
(0.059)\end{array}$ & $\begin{array}{c}0.112 \\
(0.083)\end{array}$ \\
\hline$\Delta \log$ financial system deposits & & & $\begin{array}{c}0.275 * * \\
(0.116)\end{array}$ & $\begin{array}{c}0.469 * * * \\
(0.104)\end{array}$ \\
\hline Financial development $(\mathrm{t}-(\mathrm{s}+1))$ & $\begin{array}{c}-0.001 * * * \\
(0.000)\end{array}$ & $\begin{array}{c}-0.001 * * * \\
(0.000)\end{array}$ & $\begin{array}{c}-0.001 * * * \\
(0.000)\end{array}$ & $\begin{array}{c}-0.002 * * \\
(0.001)\end{array}$ \\
\hline $\begin{array}{l}\text { Controls for quantity and unit } \\
\text { cost index, lags } 0 \text {-s }\end{array}$ & Yes & Yes & Yes & Yes \\
\hline Country FE & Yes & Yes & Yes & Yes \\
\hline Observations & 2,508 & 867 & 2,314 & 906 \\
\hline Number of countries & 114 & 41 & 113 & 41 \\
\hline R-squared & 0.472 & 0.714 & 0.491 & 0.566 \\
\hline
\end{tabular}

Notes: This table shows OLS regressions to estimate the effect of unexpected and exogenous windfall in natural resource revenue based on world prices $(\Delta$ log mineral price index) on deposit and credit growth, where we restrict the sample first to countries with no market power in any mineral (columns 1 and 2), and to only the most natural resource dependent countries (columns 3 and 4). Insignificant trailing lags of the windfall shock are dropped. $s$ is the maximum included lag length of the windfall shock. Robust standard errors are clustered by country shown in parentheses. A constant and country fixed effects are included but not shown. $* * *, * *, *$ correspond to the $1 \%, 5 \%$, and $10 \%$ level of significance, respectively. 
Table 11

OPEC countries' SWFs amplify the relative credit cycle

\begin{tabular}{|c|c|c|c|c|c|c|c|}
\hline & \multirow[b]{2}{*}{ Interaction variable: } & \multicolumn{3}{|c|}{$\Delta \log$ deposits } & \multicolumn{3}{|c|}{$\Delta \log$ private credit } \\
\hline & & $\begin{array}{c}\text { SWF } \\
\text { dummy }\end{array}$ & $\begin{array}{c}\text { non-OPEC } \\
\text { SWFs }\end{array}$ & $\begin{array}{l}\text { OPEC } \\
\text { SWFs }\end{array}$ & $\begin{array}{c}\text { SWF } \\
\text { dummy }\end{array}$ & $\begin{array}{c}\text { non-OPEC } \\
\text { SWFs }\end{array}$ & $\begin{array}{l}\text { OPEC } \\
\text { SWFs }\end{array}$ \\
\hline & & {$[1]$} & {$[2]$} & [3] & {$[1]$} & [2] & {$[3]$} \\
\hline$\Delta \log$ mineral price index & & $\begin{array}{c}-0.028^{* *} \\
(0.011)\end{array}$ & $\begin{array}{c}-0.036^{* * *} \\
(0.011)\end{array}$ & $\begin{array}{c}-0.028^{* *} \\
(0.011)\end{array}$ & $\begin{array}{l}-0.006 \\
(0.017)\end{array}$ & $\begin{array}{l}-0.010 \\
(0.017)\end{array}$ & $\begin{array}{l}-0.010 \\
(0.016)\end{array}$ \\
\hline$\Delta \log$ mineral price index $(\mathrm{t}-1)$ & & $\begin{array}{c}0.029^{* *} \\
(0.012)\end{array}$ & $\begin{array}{c}0.032 * * * \\
(0.012)\end{array}$ & $\begin{array}{c}0.027 * * \\
(0.012)\end{array}$ & $\begin{array}{l}-0.005 \\
(0.016)\end{array}$ & $\begin{array}{c}-0.008 \\
(0.016)\end{array}$ & $\begin{array}{l}-0.006 \\
(0.015)\end{array}$ \\
\hline$\Delta \log$ mineral price index $(\mathrm{t}-2)$ & & $\begin{array}{c}0.022 \\
(0.014)\end{array}$ & $\begin{array}{l}0.023^{*} \\
(0.013)\end{array}$ & $\begin{array}{l}0.024^{*} \\
(0.014)\end{array}$ & $\begin{array}{l}0.025^{*} \\
(0.014)\end{array}$ & $\begin{array}{c}0.037^{* *} \\
(0.014)\end{array}$ & $\begin{array}{l}0.025^{*} \\
(0.013)\end{array}$ \\
\hline$\Delta \log$ mineral price index $(\mathrm{t}-3)$ & & & & & $\begin{array}{l}-0.019 \\
(0.015)\end{array}$ & $\begin{array}{c}-0.014 \\
(0.016)\end{array}$ & $\begin{array}{l}-0.019 \\
(0.014)\end{array}$ \\
\hline$\Delta \log$ mineral price index $(\mathrm{t}-4)$ & & & & & $\begin{array}{c}0.026^{* *} \\
(0.011)\end{array}$ & $\begin{array}{c}0.030 * * * \\
(0.011)\end{array}$ & $\begin{array}{l}0.021 * \\
(0.011)\end{array}$ \\
\hline Direct effect of interaction variab & able & $\begin{array}{c}0.018 \\
(0.013)\end{array}$ & $\begin{array}{l}-0.004 \\
(0.013)\end{array}$ & $\begin{array}{c}0.057 * * * \\
(0.009)\end{array}$ & $\begin{array}{c}0.008 \\
(0.023)\end{array}$ & $\begin{array}{c}0.020 \\
(0.018)\end{array}$ & $\begin{array}{c}0.039 \\
(0.026)\end{array}$ \\
\hline$\Delta \log$ mineral price index & * Interaction variable (t-4) & $\begin{array}{c}-0.098^{*} \\
(0.059)\end{array}$ & $\begin{array}{c}0.086^{* *} \\
(0.041)\end{array}$ & $\begin{array}{c}-0.193 * * * \\
(0.043)\end{array}$ & $\begin{array}{c}-0.107 * * \\
(0.049)\end{array}$ & $\begin{array}{l}-0.069 \\
(0.056)\end{array}$ & $\begin{array}{c}-0.167^{* *} \\
(0.076)\end{array}$ \\
\hline$\Delta \log$ mineral price index $(\mathrm{t}-1)$ & * Interaction variable $(\mathrm{t}-4)$ & $\begin{array}{c}0.006 \\
(0.034)\end{array}$ & $\begin{array}{l}-0.053 \\
(0.039)\end{array}$ & $\begin{array}{c}0.090^{* * * *} \\
(0.029)\end{array}$ & $\begin{array}{l}-0.055 \\
(0.034)\end{array}$ & $\begin{array}{c}0.033 \\
(0.031)\end{array}$ & $\begin{array}{l}-0.067 \\
(0.049)\end{array}$ \\
\hline$\Delta \log$ mineral price index $(\mathrm{t}-2)$ & * Interaction variable $(\mathrm{t}-4)$ & $\begin{array}{c}0.025 \\
(0.030)\end{array}$ & $\begin{array}{c}0.067 * * \\
(0.030)\end{array}$ & $\begin{array}{c}0.028 \\
(0.047)\end{array}$ & $\begin{array}{c}0.123^{* *} \\
(0.052)\end{array}$ & $\begin{array}{c}0.004 \\
(0.052)\end{array}$ & $\begin{array}{c}0.218 * * * \\
(0.036)\end{array}$ \\
\hline$\Delta \log$ mineral price index $(\mathrm{t}-3)$ & * Interaction variable $(\mathrm{t}-4)$ & & & & $\begin{array}{c}0.052 \\
(0.042)\end{array}$ & $\begin{array}{c}0.018 \\
(0.052)\end{array}$ & $\begin{array}{c}0.106^{* *} \\
(0.052)\end{array}$ \\
\hline$\Delta \log$ mineral price index $(\mathrm{t}-4)$ & * Interaction variable $(\mathrm{t}-4)$ & & & & $\begin{array}{c}0.015 \\
(0.046)\end{array}$ & $\begin{array}{l}-0.071 \\
(0.069)\end{array}$ & $\begin{array}{c}0.074 \\
(0.045)\end{array}$ \\
\hline Lagged dependent variable & & $\begin{array}{c}0.330^{* * * *} \\
(0.050)\end{array}$ & $\begin{array}{c}0.333 * * * \\
(0.049)\end{array}$ & $\begin{array}{c}0.332 * * * \\
(0.050)\end{array}$ & $\begin{array}{c}-0.007 \\
(0.044)\end{array}$ & $\begin{array}{c}-0.003 \\
(0.044)\end{array}$ & $\begin{array}{l}-0.011 \\
(0.043)\end{array}$ \\
\hline Rate of inflation & & $\begin{array}{c}-0.294 * * * \\
(0.055)\end{array}$ & $\begin{array}{c}-0.301 * * * \\
(0.056)\end{array}$ & $\begin{array}{c}-0.289^{* * *} \\
(0.055)\end{array}$ & $\begin{array}{c}-0.125^{* *} \\
(0.056)\end{array}$ & $\begin{array}{c}-0.126^{* *} \\
(0.056)\end{array}$ & $\begin{array}{c}-0.126^{* *} \\
(0.056)\end{array}$ \\
\hline Rate of inflation (t-1) & & $\begin{array}{c}0.176^{* * * *} \\
(0.044)\end{array}$ & $\begin{array}{c}0.181 * * * \\
(0.043)\end{array}$ & $\begin{array}{c}0.172^{* * *} \\
(0.044)\end{array}$ & & & \\
\hline$\Delta \log$ GDP & & $\begin{array}{c}0.883^{* * *} \\
(0.025)\end{array}$ & $\begin{array}{c}0.873 * * * \\
(0.028)\end{array}$ & $\begin{array}{c}0.888^{* * *} \\
(0.025)\end{array}$ & $\begin{array}{c}0.714 * * * \\
(0.114)\end{array}$ & $\begin{array}{c}0.696^{* * * *} \\
(0.116)\end{array}$ & $\begin{array}{c}0.714 * * * \\
(0.114)\end{array}$ \\
\hline$\Delta \log$ GDP $(\mathrm{t}-1)$ & & $\begin{array}{c}-0.226^{* * *} \\
(0.053)\end{array}$ & $\begin{array}{c}-0.228^{* * *} \\
(0.051)\end{array}$ & $\begin{array}{c}-0.233 * * * \\
(0.053)\end{array}$ & $\begin{array}{c}0.217 * * * \\
(0.060)\end{array}$ & $\begin{array}{c}0.205^{* * *} \\
(0.060)\end{array}$ & $\begin{array}{c}0.222 * * * \\
(0.061)\end{array}$ \\
\hline$\Delta$ log financial system deposits & & & & & $\begin{array}{c}0.285^{* *} \\
(0.118)\end{array}$ & $\begin{array}{c}0.295^{* *} \\
(0.121)\end{array}$ & $\begin{array}{c}0.282^{* *} \\
(0.118)\end{array}$ \\
\hline Financial development $(\mathrm{t}-(\mathrm{s}+1))$ & & $\begin{array}{c}-0.000^{* * * *} \\
(0.000)\end{array}$ & $\begin{array}{c}-0.000 * * * \\
(0.000)\end{array}$ & $\begin{array}{c}-0.000 * * * \\
(0.000)\end{array}$ & $\begin{array}{c}-0.001 * * * \\
(0.000)\end{array}$ & $\begin{array}{c}-0.001 * * * \\
(0.000)\end{array}$ & $\begin{array}{c}-0.001 * * * \\
(0.000)\end{array}$ \\
\hline $\begin{array}{l}\text { Controls for quantity and unit } \\
\text { cost index, lags } 0 \text {-s }\end{array}$ & & Yes & Yes & Yes & Yes & Yes & Yes \\
\hline Country FE & & Yes & Yes & Yes & Yes & Yes & Yes \\
\hline Observations & & 2,784 & 2,784 & 2,784 & 2,579 & 2,579 & 2,579 \\
\hline Number of countries & & 122 & 122 & 122 & 121 & 121 & 121 \\
\hline R-squared & & 0.488 & 0.485 & 0.491 & 0.505 & 0.501 & 0.507 \\
\hline
\end{tabular}


Table 12

Robustness: Price shocks based on unchained (baseline) versus chained price indices

\begin{tabular}{|c|c|c|c|c|c|c|c|}
\hline & & \multicolumn{3}{|c|}{$\Delta \log$ total deposits and short-term borrowing } & \multicolumn{3}{|c|}{$\Delta \log$ private credit } \\
\hline & price index: & $\begin{array}{c}\text { Baseline: } \\
\text { Paasche, base } \\
\text { year } 1970\end{array}$ & $\begin{array}{c}\text { Laspeyres } \\
\text { chained to t-3 }\end{array}$ & $\begin{array}{l}\text { Laspeyres } \\
\text { chained to } t-5\end{array}$ & $\begin{array}{c}\text { Baseline: } \\
\text { Paasche, base } \\
\text { year } 1970\end{array}$ & $\begin{array}{c}\text { Laspeyres } \\
\text { chained to t-3 }\end{array}$ & $\begin{array}{l}\text { Laspeyres } \\
\text { chained to t-5 }\end{array}$ \\
\hline & & {$[1]$} & {$[2]$} & {$[3]$} & {$[4]$} & {$[5]$} & {$[6]$} \\
\hline$\Delta \log$ mineral price index & & $\begin{array}{c}-0.034^{* * *} \\
(0.011)\end{array}$ & $\begin{array}{c}-0.032^{* * * *} \\
(0.008)\end{array}$ & $\begin{array}{c}-0.026^{* *} \\
(0.011)\end{array}$ & $\begin{array}{l}-0.013 \\
(0.016)\end{array}$ & $\begin{array}{c}0.011 \\
(0.012)\end{array}$ & $\begin{array}{l}-0.004 \\
(0.014)\end{array}$ \\
\hline$\Delta \log$ mineral price index $(\mathrm{t}-1)$ & & $\begin{array}{c}0.030^{* *} \\
(0.012)\end{array}$ & $\begin{array}{c}0.013 \\
(0.010)\end{array}$ & $\begin{array}{c}0.009 \\
(0.018)\end{array}$ & $\begin{array}{l}-0.008 \\
(0.015)\end{array}$ & $\begin{array}{l}-0.018^{*} \\
(0.010)\end{array}$ & $\begin{array}{c}0.000 \\
(0.015)\end{array}$ \\
\hline$\Delta \log$ mineral price index $(\mathrm{t}-2)$ & & $\begin{array}{l}0.025^{*} \\
(0.013)\end{array}$ & $\begin{array}{l}-0.004 \\
(0.010)\end{array}$ & $\begin{array}{c}0.007 \\
(0.008)\end{array}$ & $\begin{array}{c}0.036^{* * * *} \\
(0.014)\end{array}$ & $\begin{array}{c}0.028 * * * \\
(0.010)\end{array}$ & $\begin{array}{c}0.011 \\
(0.011)\end{array}$ \\
\hline$\Delta \log$ mineral price index $(\mathrm{t}-3)$ & & & & $\begin{array}{l}-0.013 \\
(0.013)\end{array}$ & $\begin{array}{l}-0.014 \\
(0.015)\end{array}$ & & $\begin{array}{c}0.004 \\
(0.012)\end{array}$ \\
\hline$\Delta \log$ mineral price index $(\mathrm{t}-4)$ & & & & $\begin{array}{l}-0.003 \\
(0.008)\end{array}$ & $\begin{array}{l}0.026^{* *} \\
(0.011)\end{array}$ & & $\begin{array}{l}0.024^{*} \\
(0.012)\end{array}$ \\
\hline Lagged dependent variable & & $\begin{array}{c}0.333 * * * \\
(0.049)\end{array}$ & $\begin{array}{c}0.297 * * * \\
(0.028)\end{array}$ & $\begin{array}{c}0.323 * * * \\
(0.026)\end{array}$ & $\begin{array}{l}-0.003 \\
(0.044)\end{array}$ & $\begin{array}{l}-0.010 \\
(0.042)\end{array}$ & $\begin{array}{c}0.007 \\
(0.042)\end{array}$ \\
\hline Rate of inflation & & $\begin{array}{c}-0.302 * * * \\
(0.056)\end{array}$ & $\begin{array}{c}-0.294 * * * \\
(0.056)\end{array}$ & $\begin{array}{c}-0.274 * * * \\
(0.066)\end{array}$ & $\begin{array}{c}-0.126^{* *} \\
(0.056)\end{array}$ & $\begin{array}{c}-0.135 * * \\
(0.057)\end{array}$ & $\begin{array}{c}-0.134 * * \\
(0.058)\end{array}$ \\
\hline Rate of inflation (t-1) & & $\begin{array}{c}0.181 * * * \\
(0.043)\end{array}$ & $\begin{array}{c}0.184 * * * \\
(0.043)\end{array}$ & $\begin{array}{c}0.179 * * * \\
(0.049)\end{array}$ & & & \\
\hline$\Delta \log$ GDP & & $\begin{array}{c}0.872 * * * \\
(0.028)\end{array}$ & $\begin{array}{c}0.890^{* * * *} \\
(0.023)\end{array}$ & $\begin{array}{c}0.890^{* * * *} \\
(0.023)\end{array}$ & $\begin{array}{c}0.696^{* * *} \\
(0.115)\end{array}$ & $\begin{array}{c}0.706 * * * \\
(0.123)\end{array}$ & $\begin{array}{c}0.723 * * * \\
(0.119)\end{array}$ \\
\hline$\Delta \log$ GDP $(\mathrm{t}-1)$ & & $\begin{array}{c}-0.228 * * * \\
(0.051)\end{array}$ & $\begin{array}{c}-0.196 * * * \\
(0.037)\end{array}$ & $\begin{array}{c}-0.208^{* * *} \\
(0.036)\end{array}$ & $\begin{array}{c}0.204 * * * \\
(0.059)\end{array}$ & $\begin{array}{c}0.210^{* * * *} \\
(0.058)\end{array}$ & $\begin{array}{c}0.223 * * * \\
(0.062)\end{array}$ \\
\hline$\Delta \log$ financial system deposits & & & & & $\begin{array}{c}0.294 * * \\
(0.120)\end{array}$ & $\begin{array}{c}0.309 * * \\
(0.127)\end{array}$ & $\begin{array}{c}0.268^{* *} \\
(0.123)\end{array}$ \\
\hline Financial development $(\mathrm{t}-(\mathrm{s}+1)$ & & $\begin{array}{c}-0.000 * * * \\
(0.000)\end{array}$ & $\begin{array}{c}-0.000 * * * \\
(0.000)\end{array}$ & $\begin{array}{c}-0.000^{* *} \\
(0.000)\end{array}$ & $\begin{array}{c}-0.001 * * * \\
(0.000)\end{array}$ & $\begin{array}{c}-0.001 * * * \\
(0.000)\end{array}$ & $\begin{array}{c}-0.001 * * * \\
(0.000)\end{array}$ \\
\hline $\begin{array}{l}\text { Controls for quantity and unit cost } \\
\text { index, lags } 0 \text {-s }\end{array}$ & & Yes & Yes & Yes & Yes & Yes & Yes \\
\hline Country FE & & Yes & Yes & Yes & Yes & Yes & Yes \\
\hline Observations & & 2,784 & 2,597 & 2,215 & 2,579 & 2,611 & 2,230 \\
\hline Number of countries & & 122 & 120 & 119 & 121 & 120 & 119 \\
\hline Years & & $1973-2008$ & $1976-2008$ & $1980-2008$ & $1975-2008$ & $1976-2008$ & $1980-2008$ \\
\hline R-squared & & 0.484 & 0.489 & 0.481 & 0.499 & 0.510 & 0.508 \\
\hline
\end{tabular}

Notes: This table shows OLS regressions to estimate the effect of unexpected and exogenous windfall in natural resource revenue based on world prices ( $\Delta$ log mineral price index, Paasche base year 1970) on deposit and credit growth. $s$ is the maximum included lag length of the windfall shock. $\Delta$ log mineral price index, Laspeyres chained to $t-1$ allows the base year to vary but sets the base year for time $t$ at year $t-1$. $\Delta \log$ mineral price index, Laspeyres chained to $t-1$ allows the base year to vary but sets the base year for time $t$ at year $t-2$. $\Delta$ log mineral price index, Laspeyres chained to $t-1$

shown $* * * * * * *$ correspond to the $1 \%, 5 \%$, and $10 \%$ level of significance, respectively. 


\section{Table A1}

\section{Variable definitions and data sources}

\begin{tabular}{|c|c|c|c|c|c|c|c|}
\hline & $\mathrm{N}$ & mean & s.d. & $\min$ & $\max$ & Definition & Source \\
\hline \multicolumn{8}{|l|}{ Dependent variables: } \\
\hline Private credit/GDP & 4,522 & 0.407 & 0.366 & 0.001 & 2.698 & $\%$ Private credit of GDP & Beck et al. \\
\hline bank deposits over GDP & 4,532 & 0.41 & 0.369 & 0.001 & 4.292 & $\%$ bank deposits of GDP & Beck et al. \\
\hline$\Delta$ gross domestic savings ( $\%$ of GDP) & 3,535 & 0.064 & 5.416 & -49.93 & 72.555 & change in gross domestic savings ( $\%$ of GDP) & World Bank \\
\hline$\Delta$ log gross domestic savings & 3,323 & 0.089 & 0.433 & -4.21 & 3.779 & log difference of gross domestic savings (current US\$) & World Bank \\
\hline$\Delta \log$ household final consumption expenditure & 3,465 & 0.08 & 0.157 & -1.343 & 1.205 & log difference of household final consumption expenditure (current US\$) & World Bank \\
\hline$\Delta \log$ final consumption expenditure minus household final con: & 3,080 & 0.079 & 0.227 & -4.904 & 5.078 & $\begin{array}{l}\text { log difference of final consumption expenditure (current US\$) minus household final } \\
\text { consumption expenditure (current US\$) }\end{array}$ & World Bank \\
\hline$\Delta \log$ financial system deposits & 3,042 & 0.112 & 0.194 & -4.432 & 1.154 & log difference of financial system deposits & Beck et al. \\
\hline Deposit rate & & & & & & IFS line $60 \mathrm{~L} \_Z \mathrm{ZF}$, deposit rate & IMF \\
\hline$\Delta \log$ bank deposits & 3,041 & 0.112 & 0.194 & -4.432 & 1.154 & log difference of bank deposits & Beck et al. \\
\hline$\Delta \log$ offshore bank deposits & 1,280 & 0.111 & 0.314 & -2.208 & 3.046 & log difference of offshore bank deposits & Beck et al. \\
\hline$\Delta \log$ foreign assets (banking institutionsitutions) & 2,555 & 0.129 & 0.447 & -6.425 & 4.154 & log difference of foreign assets (IFS line 21) & IMF \\
\hline$\Delta$ log government deposits with central bank & 2,482 & 0.102 & 1.037 & -7.613 & 28.065 & log difference of central government deposits with central bank (IFS line 16D) & IMF \\
\hline$\Delta$ log government deposits with banks & 2,420 & 0.091 & 0.546 & -4.339 & 7.686 & log difference of central government deposits with banks (IFS line 26D_ZF) & IMF \\
\hline$\Delta \log$ private credit & 3,033 & 0.111 & 0.224 & -1.864 & 2.041 & $\log$ difference of private credit & World Bank \\
\hline$\Delta$ log claims on central government & 2,592 & 0.112 & 0.694 & -10.04 & 8.794 & log difference of claims on central government (IFS line 22A) & IMF \\
\hline$\Delta \log$ claims on state and local governments & 907 & 0.08 & 1.05 & -6.63 & 8.109 & log difference of claims on state and local governments (IFS line 22B) & IMF \\
\hline$\Delta$ log claims on public non-financial corp. & 1,198 & 0.076 & 0.715 & -5.807 & 8.881 & log difference of claims on public non-financial corporations (IFS line 22C) & IMF \\
\hline$\Delta$ net foreign borrowing over GDP ((liabilities-assets)/GDP) & 3,111 & 0 & 0.062 & -1.822 & 1.588 & $\begin{array}{l}\text { change in net foreign borrowing over GDP (IFS line 26C (liabilities) minus } 21 \\
\text { (assets) divided by GDP) }\end{array}$ & IMF \\
\hline$\Delta \log$ total assets & 5,684 & 0.127 & 0.123 & -1.541 & 2.583 & $\begin{array}{l}\text { log difference of total assets in millions of current USD. Equals the sum of Portfolio } \\
\text { equity assets (stock), FDI assets (stock), Debt assets (stock), financial derivatives } \\
\text { (assets), and FX Reserves minus gold. }\end{array}$ & $\begin{array}{l}\text { updated and extended } \\
\text { version of dataset } \\
\text { constructed by Lane and } \\
\text { Milesi-Ferretti (2007) }\end{array}$ \\
\hline$\Delta \log$ total liabilities & 5,691 & 0.120 & 0.103 & -1.242 & 4.231 & $\log$ difference of total liabilities in millions of current USD & idem \\
\hline$\Delta \log$ gross debt liabilities & 5,723 & 0.111 & 0.088 & -1.668 & 10.206 & $\log$ difference of debt liabilities in millions of current USD & idem \\
\hline$\Delta$ log Bank's total deposits and short-term borrowing & 9,906 & 0.0939 & 0.4605 & -7.29 & 7.25 & $\begin{array}{l}\text { log difference of Total Customer Deposits }+ \text { Other Deposits and Short-term } \\
\text { Borrowings (data2031+data2033) }\end{array}$ & Bankscope \\
\hline$\Delta$ log Bank's gross loans & 9,874 & 0.1059 & 0.4539 & -7.861 & 6.3968 & log difference of gross loans (data2001) & Bankscope \\
\hline$\Delta$ Bank's nonperfoming loans to total gross loans (\%) & 508 & -1.096 & -0.5 & -25 & 20.1 & log difference of bank nonperfoming loans to total gross loans (\%) & World Bank \\
\hline \multicolumn{8}{|l|}{ Independent variables: } \\
\hline Resource rents over GDP & 4,522 & 0.054 & 0.123 & 0 & 1.165 & $\begin{array}{l}\% \text { Total metals and mineral rents of GDP. production * (price-unit production cost) } \\
\text { of oil, gas, coal, bauxite, copper, lead, nickel, phosphate, tin, zinc, gold, silver, iron } \\
\text { ore. Missing observations are counted as zero. }\end{array}$ & World Bank \\
\hline $\log$ GDP per capita & 4,522 & 7.713 & 1.575 & 4.4 & 10.936 & $\log$ GDP per capita & World Bank \\
\hline Institutions & 1,680 & 24.614 & 6.016 & 5 & 38.29 & $\begin{array}{l}\text { Sum of corruption, rule of law, government stability, investment profile and } \\
\text { bureacratic quality }\end{array}$ & ICRG \\
\hline$\Delta \log$ resource price index & 3,042 & 0.077 & 0.237 & -0.929 & 1.584 & log difference in Paasche price index of metals and minerals, with base year 1970 & World Bank \\
\hline
\end{tabular}


$\Delta \log$ resource quantity index

$\Delta \log$ resource unit cost index

Financial development

rate of inflation

$\Delta \log$ GDP

$\Delta \log$ non-mineral GDP

$\Delta \log$ real exchange rate

Bank's log total assets

Bank's Net Loans / Tot Assets

$\Delta \log$ global deposits

Bank foreign owned

Bank's non-interest share of total operating income

Interest rate controls (t-1)

International capital controls (t-1)

Financial reform index $[0,1](t-1)$

$2,638 \quad 0.494 \quad 0.512$

$2,638 \quad 1.602 \quad 1.5$

0

Credit controls (t-1)

Credit ceilings (t-1)

Directed credit (t-1)

$\Delta \log$ hydrocarbon price index

$\Delta \log$ hydrocarbon quantity index

$\Delta \log$ hydrocarbon unit cost index

Giant oil and gas field discovery dummy

log giant oil and gas field ultimately recoverable reserves discor

Sovereign wealth fund dummy

Notes: This table gives the definition, solrch $\begin{array}{lllll}3,042 & 0.028 & 0.364 & -5.118 & 4.886\end{array}$

$\begin{array}{lllll}3,042 & 0.058 & 0.12 & -0.758 & 1.701\end{array} \quad$ log difference in Paasche unit production cost index of metals and minerals, with

$\begin{array}{llllll}3,042 & 0.116 & 0.233 & -0.297 & 4.823 & \text { private credit over GDP }\end{array}$

og difference of current GDP

$\log$ difference of current GDP net of ores, metals and fuel exports

$6,893 \quad 0.0407 \quad 0.0414-1.116 \quad 2.541 \quad \log$ difference of the price level of GDP, price level of USA GDP in $2005=1$

$\begin{array}{llllll}9,906 & 8.0741 & 2.4247 & -0.087 & 17.966 & \log \text { total assets (data2025) }\end{array}$

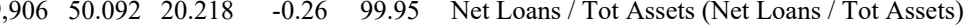

$\begin{array}{lllll}0.1221 & 0.1029 & -0.012 & 0.4894 & \text { log difference of global sum of deposits (data2025) }\end{array}$

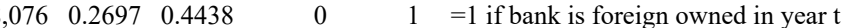

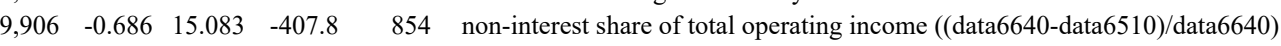

World Bank

World Bank

World Bank

World Bank

World Bank

World Bank

Feenstra et al. (2015)

Bankscope

Bankscope

Bankscope

Claessen and van Horen

Bankscope

Abiad et al.

0 to 3 in integer steps from fully repressec
control over deposit and lending rates.

0 to 3 in integer steps from fully repressed to fully liberalized based on Is the

3 exchange rate system unified?, Does a country set restrictions on capital inflow?, Abiad et al. Does a country set restrictions on capital outflow?

0 to 1 , continuous. Based on sum of indices of liberalization in Banking Sector

Supervision, Securities Markets, Privatization, Capital Account Transactions,

Banking Sector Entry, Interest Rate Liberalization, Aggregate Credit Ceilings,

Credit Controls and Reserve Requirements, normalized to $[0,1]$

0 to 3 in steps of 0.25 to fully liberalized based on Are reserve requirements

3 restrictive?, Are there minimum amounts of credit that must be channeled to certain Abiad et al. sectors?, Are there any credits supplied to certain sectors at subsidized rates?

0 or 1 to fully liberalized based on whether restrictions exist on the expansion of bank credit

0 to 3 in integer to fully liberalized based on Are there minimum amounts of credit

3 that must be channeled to certain sectors?, Are there any credits supplied to certain Abiad et al. sectors at subsidized rates?

$\begin{array}{llllll}2,416 & 0.086 & 0.246 & -0.675 & 1.647 & \log \text { difference in Paasche price index of hydrocarbons, with base year } 1970\end{array}$ World Bank

$\begin{array}{lllllll}2,416 & 0.036 & 0.393 & -6.942 & 3.823 & \text { log difference in metals and minerals revenu divided by Paasche price index of } & \text { World Bank }\end{array}$

$\begin{array}{llllll}2,416 & 0.077 & 0.15 & -0.924 & 1.598 & \log \text { difference in Paasche unit production cost index of hydrocarbons, with base year }\end{array}$ World Bank

$\begin{array}{llllll}2,784 & 0.048 & 0.2141 & 0 & 1 & \begin{array}{l}=1 \text { if a giant oil or gas field is discovered in year t of at least } 500 \text { million of barrels of } \\ \text { oil equivalent (MMBOE) ultimately recoverable reserves. }\end{array}\end{array}$

$09.4859 \log$ of sum of total MMBOE ultimately recoverable reserves discovered in year Horn (2003)

$3,042 \quad 0.068 \quad 0.2524 \quad 0 \quad 1=1$ if country has a commodity based sovereign wealth fund in year $\mathrm{t}$.

$\begin{array}{lll}0 & 1 & \text { http://www.swfinstitute.org/fund-rankings/ }\end{array}$

SWF Institute 
Table A2

Growth in natural resource rents and its components

\begin{tabular}{lc}
\hline \hline & $\Delta$ Total mineral rents \\
\cline { 2 - 2 }$\Delta$ log mineral price index & {$[1]$} \\
\cline { 2 - 2 }$\Delta$ log mineral quantity index & $(0.042)$ \\
& $0.555^{* * *}$ \\
$\Delta$ log mineral unit cost index & $(0.058)$ \\
& $-0.297^{* *}$ \\
Country FE & $(0.119)$ \\
Observations & Yes \\
Number of countries & 4,603 \\
R-squared & 146 \\
\hline \hline & 0.578 \\
\hline Notes: This table shows an OLS regressions to estimate the relationship between \\
growth in total mineral rents and the separate effect of shocks to prices, quantities and \\
unit costs. An F-test rejects that the sum of the coefficients is different from 1. Robust \\
standard errors are clustered by country shown in parentheses. A constant and country \\
fixed effects are included but not shown. ***, **, * correspond to the $1 \%, 5 \%$, and \\
10\% level of significance, respectively.
\end{tabular}

